\title{
Investigation of the 2013 Alberta flood from weather and climate perspectives
}

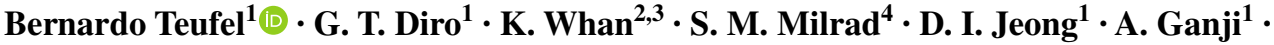

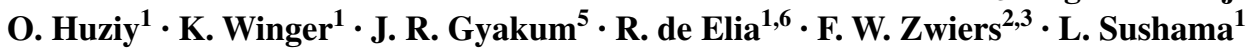

Received: 13 February 2016 / Accepted: 13 June 2016 / Published online: 23 June 2016

(C) The Author(s) 2016. This article is published with open access at Springerlink.com

\begin{abstract}
During 19-21 June 2013 a heavy precipitation event affected southern Alberta and adjoining regions, leading to severe flood damage in numerous communities and resulting in the costliest natural disaster in Canadian history. This flood was caused by a combination of meteorological and hydrological factors, which are investigated from weather and climate perspectives with the fifth generation Canadian Regional Climate Model. Results show that the contribution of orographic ascent to precipitation was important, exceeding $30 \%$ over the foothills of the Rocky Mountains. Another contributing factor was evapotranspiration from the land surface, which is found to have acted as an important moisture source and was likely enhanced by antecedent rainfall that increased soil moisture over the northern Great Plains. Event attribution analysis suggests that human induced greenhouse gas increases may also have contributed by causing evapotranspiration rates to be higher than they would have been under pre-industrial
\end{abstract}

Electronic supplementary material The online version of this article (doi:10.1007/s00382-016-3239-8) contains supplementary material, which is available to authorized users.

Bernardo Teufel

teufel@sca.uqam.ca

1 Centre ESCER, University of Quebec at Montreal, Case postale 8888, succursale Centre-Ville, Montreal, QC H3C 3P8, Canada

2 University of Victoria, Victoria, BC, Canada

3 Pacific Climate Impacts Consortium, Victoria, BC, Canada

4 Embry-Riddle Aeronautical University, Daytona Beach, FL, USA

5 McGill University, Montreal, QC, Canada

6 Ouranos Consortium, Montreal, QC, Canada conditions. Frozen and snow-covered soils at high elevations are likely to have played an important role in generating record streamflows. Results point to a doubling of surface runoff due to the frozen conditions, while $25 \%$ of the modelled runoff originated from snowmelt. The estimated return time of the 3-day precipitation event exceeds 50 years over a large region, and an increase in the occurrence of similar extreme precipitation events is projected by the end of the 21st century. Event attribution analysis suggests that greenhouse gas increases may have increased 1-day and 3-day return levels of May-June precipitation with respect to pre-industrial climate conditions. However, no anthropogenic influence can be detected for 1-day and 3-day surface runoff, as increases in extreme precipitation in the present-day climate are offset by decreased snow cover and lower frozen water content in soils during the May-June transition months, compared to pre-industrial climate.

Keywords 2013 Alberta flood · Land-atmosphere · Orographic forcing $\cdot$ Hydrology $\cdot$ Climate change $\cdot$ Event attribution

\section{Introduction}

The 2013 Alberta flood was the costliest natural disaster in Canadian history, with damages exceeding CAD \$6 billion (Milrad et al. 2015; Pomeroy et al. 2016). Moderate to heavy rainfall affected a broad area of southern Alberta (Fig. 1a) for a long period (19-21 June), leading to rapid increases in water levels along the Bow River and its tributaries, which resulted in numerous communities suffering severe flood damage. The flood caused four deaths, forced tens of thousands of Albertans to leave their homes, 
Fig. 1 a The southern Alberta region affected by the flood event. The inset shows the location of this region within Canada. The colours show the topography. Also shown are the rain gauges (yellow triangles) and streamflow gauges (red dots), with the delineation of the Bow River basin in red. b Experimental domain of CRCM5 simulations in the LAM $0.11^{\circ}$ configuration, with every tenth grid point shown. c Experimental domain of CRCM5 simulations in the GVAR configuration, with every fifth grid point shown

(a)

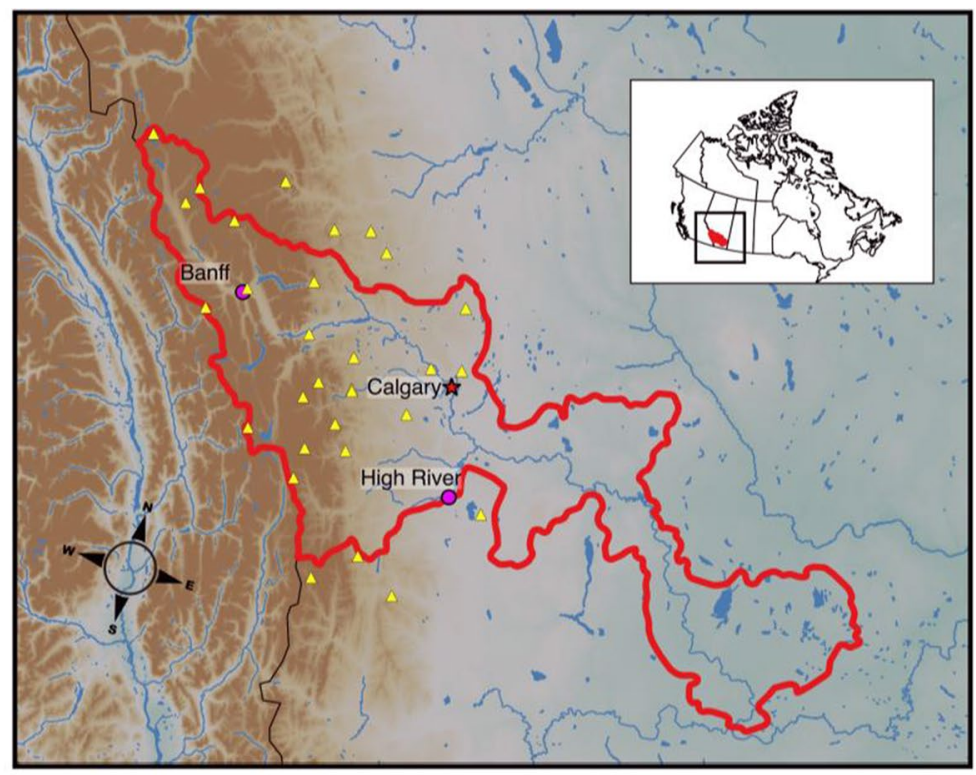

Legend

$\triangle$ Weather stations $\square$ Bow river basin Topography (m)

0.0

100

200

$\square 00$
$\square$
$\square 00$

$\square$
$\square$
$\square$
$\square$

600

$\square 00$
$\square \quad 800$

$\square 900$

$\square$
$\square \quad 1000$

$\square \quad 1100$

$\square 1200$

$\square$
$\square$
$\square$
$\square$

$\square 1500$

$\square 1600$

$\square \quad 1700$

1800

1900
2000

(b)

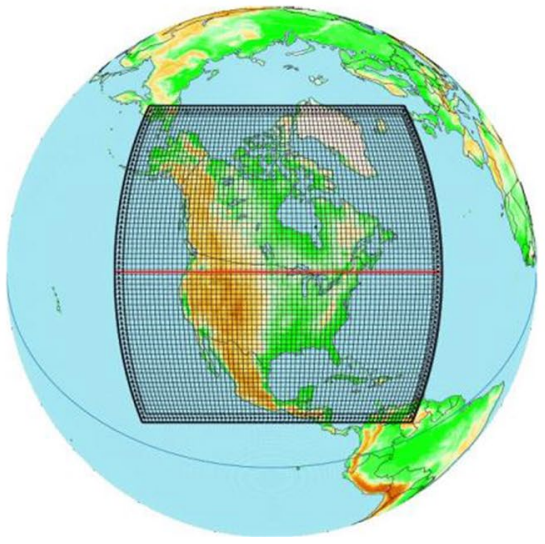

(c)

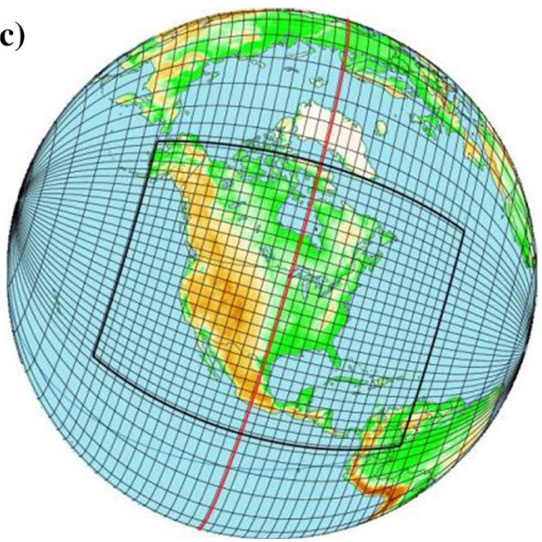

destroyed $1000 \mathrm{~km}$ of roads and washed away hundreds of bridges and culverts (Environment Canada 2014). From a historical viewpoint, the water levels along the Bow River were the highest in the past 60 years. According to Pomeroy et al. (2016), the return time of the streamflows is around 40 years for the Bow River at Banff and at Calgary, based on gauged and estimated streamflows at these two locations.

The 2013 flood was caused by a combination of meteorological and hydrological factors. The meteorological environment was characterized by a lee cyclone that developed over southern Montana on 19 June and deepened quickly, creating strong low-level easterly (upslope) flow throughout southern Alberta. A combination of quasigeostrophically and orographically forced ascent acted to release instability, resulting in heavy precipitation. The stagnant synopticscale pattern contributed to the persistence and duration of the rainfall (Milrad et al. 2015). On the hydrological side, soils in high elevation areas were saturated and/or frozen, offering little capacity to store additional water, thus contributing to the magnitude of the flooding. Additionally, the rain fell on snow over the upper elevations of the Bow River basin (BRB), which is estimated to have contributed up to an additional $100 \mathrm{~mm}$ of runoff derived from snowmelt (Pomeroy et al. 2016).

Although many of the factors that contributed to this flood event have been identified (Milrad et al. 2015; Pomeroy et al. 2016), the relative importance of each of these factors remains unclear. Thus, the goal of this paper is to investigate the flood from weather and climate perspectives, through targeted experiments with the fifth generation Canadian Regional Climate Model (CRCM5; Martynov et al. 2013). From the weather perspective, the aim is to advance the understanding of different processes that contributed to this event and to assess their relative importance. Investigation of the event with CRCM5 also provides helpful insight about the performance of CRCM5 at shorter time scales. From the climate perspective, the role of human influence on the probability of occurrence of such an event in present-day and future climates is analyzed. 
An important process to investigate from the weather perspective is the modification of air masses due to land-atmosphere interaction prior to and during the flooding event, as the land surface can act as a significant source of moisture to the atmosphere during the warm season (Brubaker et al. 1993). This investigation is supported by the backward trajectories analyzed by Milrad et al. (2015), which show that air parcels associated with heavy precipitation during the event track back to the Northern Plains, suggesting that evapotranspiration (ET) from this region would have acted as a moisture source. The contribution of local ET, i.e. in the vicinity of the precipitation event, also needs to be quantified and understood. In addition, given the proximity to the Rocky Mountains, the impact of orographic forcing on precipitation is also addressed (Flesch and Reuter 2012; Milrad et al. 2015). Owing to the lack of observations, the impact of the land surface state on the magnitude of the hydrological flood, i.e. streamflows, can only be quantified through modelling. In particular, the contribution of snowmelt (from direct and rain-on-snow processes) and the impact of soil moisture level and phase (i.e. frozen vs. liquid) have been suggested as important factors during this event, which are explored through CRCM5 experiments.

From the climate perspective, the aim is to investigate the frequency of occurrence of a precipitation event similar in magnitude to the Alberta flood event and whether this frequency is projected to change during the 21 st century given climate change. Global warming is expected to increase the frequency and magnitude of extreme precipitation events, as a warmer atmosphere is able to hold more water vapour, meaning that more moisture is available to form precipitation and additional energy is available to further intensify such events (e.g. Kharin et al. 2013). It is also the aim to explore how anthropogenic emissions may have altered the probability of occurrence of this event, an analysis generally referred to as event attribution. This study follows the 'attributable risk' approach, which tries to quantify how much an external climate driver, such as increased greenhouse gas (GHG) concentrations, may have increased or decreased the probability of occurrence of an event of comparable magnitude (Stott et al. 2004).

The rest of the paper is organized as follows. Section 2 describes the model used in this study. Section 3 outlines the various experiments performed and Sect. 4 discusses the observed and modelled evolution of the event. Section 5 presents the investigation from the weather perspective, while Sect. 6 presents the climate perspective, followed by a summary and conclusions in Sect. 7.

\section{Model}

The regional climate model used in this study is CRCM5 (Martynov et al. 2013), which is based on the Global
Environment Multiscale (GEM) model used for numerical weather prediction at Environment Canada (Cote et al. 1998). It employs semi-Lagrangian transport and a (quasi) fully implicit time stepping scheme. In its fully elastic nonhydrostatic formulation (Yeh et al. 2002), it uses a vertical coordinate based on hydrostatic pressure (Laprise 1992). The CRCM5 physics package includes: deep convection following Kain and Fritsch (1990), shallow convection based on a transient version of the Kuo (1965) scheme (Belair et al. 2005), large-scale condensation (Sundqvist et al. 1989), correlated $\mathrm{K}$ solar and terrestrial radiation ( $\mathrm{Li}$ and Barker 2005), subgrid-scale orographic gravity wave drag (Mcfarlane 1987), low-level orographic blocking (Zadra et al. 2003), and turbulent kinetic energy closure in the planetary boundary layer and vertical diffusion (Benoit et al. 1989; Delage 1997; Delage and Girard 1992).

CRCM5 is generally used in a limited area (LAM) configuration, as adequate lateral boundary conditions are usually available. However, the model can also be used in a global variable-resolution (GVAR) mode, with high resolution over the region of interest. For example, Caron et al. (2011) used the GVAR configuration to study tropical cyclones, while Markovic et al. (2012) assessed the added value of GVAR in the context of seasonal forecasts. This study uses the LAM configuration at $0.11^{\circ}$ and $0.44^{\circ}$ resolution, with the exception of event attribution, where a GVAR configuration, with $0.5^{\circ}$ resolution over North America and $2^{\circ}$ elsewhere, is used.

CRCM5 uses the CLASS v3.5 land surface scheme (Verseghy 2011). Streamflows are generated for the BRB from the CRCM5 simulated runoff with the WATROUTE hydrological routing scheme (Poitras et al. 2011; Soulis et al. 2000). The flow directions, river lengths and slopes required by the routing scheme are derived from the HydroSHEDS database (Lehner et al. 2008), available at 30-s spatial resolution, following the upscaling method employed by Huziy et al. (2013).

\section{Methods}

As discussed earlier, from the weather perspective this study focuses on quantifying the roles of orography, local and remote moisture sources, the occurrence of rain-onsnow and soil moisture phase in the Alberta flood event through the analysis of CRCM5 experiments. An ensemble of nine CRCM5 reference simulations (CRCM5_Ref) only differing in their initial conditions serves to evaluate the performance of the model and to help assess the significance of the various factors that may have contributed to the flood event. The CRCM5_Ref integrations are initialized six hours apart between 0000 UTC 12 June and 0000 UTC 14 June 2013, continuing until 0000 UTC 22 
Table 1 Simulations considered in this study

\begin{tabular}{|c|c|c|c|}
\hline Name & Resolution & Period & Notes \\
\hline \multicolumn{4}{|l|}{ LAM configuration } \\
\hline \multicolumn{4}{|c|}{ Weather (short simulations) } \\
\hline CRCM5_Ref & $0.11^{\circ}$ & 14-21 June 2013 & Reference $^{\mathrm{a}}$ \\
\hline CRCM5_Oro & & & Reduced orography \\
\hline CRCM5_dryair & & & Dry air over $\mathrm{AB}, \mathrm{GP}$ and $\mathrm{CP}$ \\
\hline CRCM5_SMdryGP & & & Dry soil in Great Plains \\
\hline CRCM5_SMwetGP & & & Saturated soil in Great Plains \\
\hline CRCM5_SMdryAB & & & Dry soil in Alberta \\
\hline CRCM5_SMwetAB & & & Saturated soil in Alberta \\
\hline CRCM5_SMdryCP & & & Dry soil in east Canadian Prairies \\
\hline CRCM5_SMwetCP & & & Saturated soil in east Canadian Prairies \\
\hline CRCM5_nosnow & & & Initialized with zero snow (BRB) \\
\hline CRCM5_unfrozen & & & Initialized with zero snow + frozen soil $(\mathrm{BRB})$ \\
\hline \multicolumn{4}{|c|}{ Climate (long simulations) } \\
\hline CRCM5_ERA & $0.11^{\circ}$ & $1981-2010$ & Driven by ERA-Interim \\
\hline $\begin{array}{l}\text { CRCM5_ } \\
\text { CanESM2_4.5 }\end{array}$ & $0.44^{\circ}$ & $1950-2100$ & Driven by CanESM2 for RCP4.5 \\
\hline $\begin{array}{l}\text { CRCM5_ } \\
\text { CanESM2_8.5 }\end{array}$ & $0.44^{\circ}$ & $1950-2100$ & Driven by CanESM2 for RCP8.5 \\
\hline \multicolumn{4}{|c|}{ GVAR configuration (event attribution) } \\
\hline CRCM5_Ind & $0.5^{\circ}$ & 2013 & Present-day, SST from ERA-Interim ${ }^{\mathrm{b}}$ \\
\hline CRCM5_preInd1 & & & Pre-industrial, $\Delta \mathrm{SST}$ from CanESM $2^{\mathrm{b}}$ \\
\hline CRCM5_preInd2 & & & Pre-industrial, $\Delta \mathrm{SST}$ from $\mathrm{GFDL}^{\mathrm{b}}$ \\
\hline CRCM5_preInd3 & & & Pre-industrial, $\Delta$ SST from GISS ${ }^{b}$ \\
\hline
\end{tabular}

June 2013. The simulations are performed in LAM mode with $0.11^{\circ}$ resolution (Fig. $1 b$ ), and are driven by the ERAInterim reanalysis (Dee et al. 2011) at the lateral boundaries. Spectral nudging is applied to the temperature field and the horizontal wind components, with a half-response wavelength of $410 \mathrm{~km}$ and a relaxation time of $24 \mathrm{~h}$. Nudging strength is set to zero at the surface and increases with height, reaching full strength above the lowest $15 \%$ of the atmospheric column. For all simulations, unless specified otherwise, the atmosphere is initialized from ERA-Interim fields and the soil is initialized using fields from a continuous ERA-Interim driven run of CRCM5 over the same domain. As accurate surface conditions are critical for the simulation of streamflows, initial snow depth, snow density and snow temperature in the BRB (Fig. 1a) are taken from the Snow Data Assimilation System (SNODAS; Barrett 2003), and the soil is considered frozen for grid cells covered by snow. Initial conditions for WATROUTE are obtained from a spin-up hydrologic simulation, which uses CRCM5-simulated runoff and starts in January 2013.
The performance of CRCM5_Ref in representing precipitation, the main synoptic-dynamic characteristics of the event and streamflow in the BRB is first assessed. To this end, the simulated precipitation is compared to Environment Canada's six-hourly Canadian Precipitation Analysis (CaPA; Mahfouf et al. 2007), available at $15 \mathrm{~km}$ spatial resolution, and to the daily ANUSPLIN gridded dataset (McKenney et al. 2011), available at $10 \mathrm{~km}$ spatial resolution. Hourly rainfall accumulations from 30 rain gauges of Alberta's AgroClimatic Information Service, located in and around the western BRB are also used (Fig. 1a). The six-hourly ERA-Interim reanalysis at $0.75^{\circ}$ spatial resolution is used to evaluate simulated synoptic and dynamic features, such as geopotential heights, upper and lower level circulations and vertically integrated moisture fluxes. Finally, the hydrographs generated by CRCM5 and WATROUTE are compared to those from two flow monitoring stations on the Bow River, one located at Banff and the other at Calgary (Fig. 1a). All experiments performed, from weather and climate perspectives, are discussed below and summarized in Table 1. 
Fig. 2 Terrain elevation (m) over Alberta and adjoining regions in: a CRCM5_Ref and b CRCM5_Oro. c Regions where moisture is altered during different experiments: Alberta in red, the east Canadian Prairies in blue and the Great Plains in green

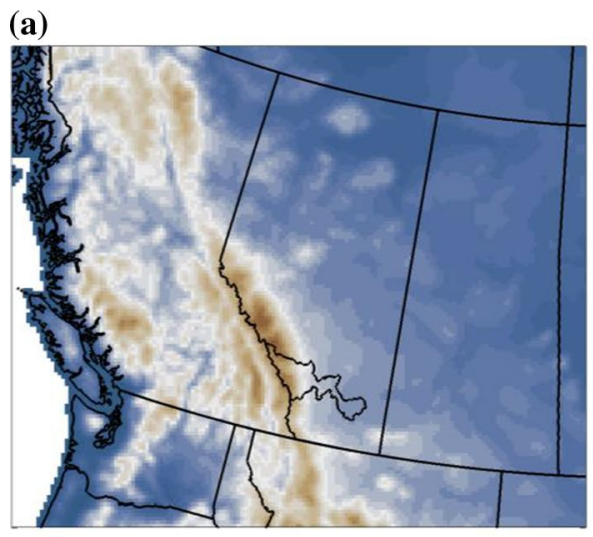

(b)

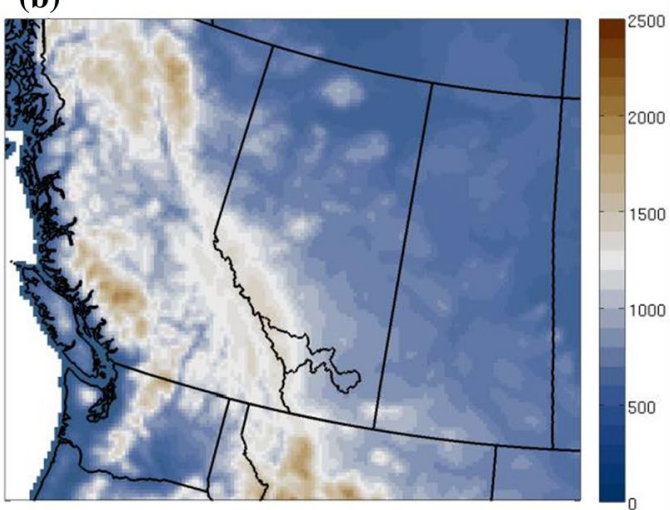

(c)

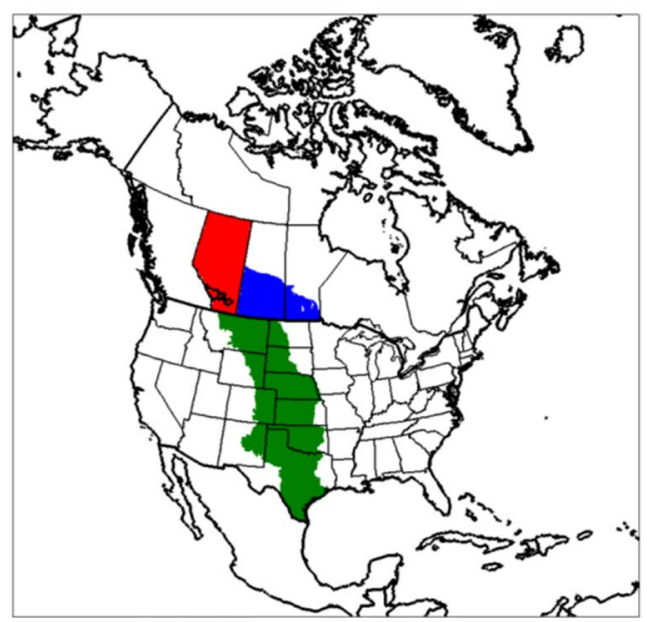

\subsection{Impact of orography}

Milrad et al. (2015) concluded that orographically forced ascent played a role during the event. Here, the impact of orography on the location and intensity of precipitation is quantified by performing an experiment (CRCM5_Oro) with reduced orography over the southern Canadian Rockies, i.e. by reducing terrain heights above $1200 \mathrm{~m}$ by $75 \%$, following an approach similar to Flesch and Reuter (2012). The orography used for CRCM5_Ref and the reduced orography used for CRCM5_Oro are shown in Fig. 2a, b. Differences in precipitation are quantified and linked to differences in the moisture flux convergence, which originate from the expected differences in atmospheric circulation.

\subsection{Impact of antecedent atmospheric moisture}

Moisture already present in the atmosphere on 14 June, when high values of vertically integrated water vapour (IWV exceeding $25 \mathrm{~mm}$ ) extended from the southern US into Saskatchewan and Montana, might have contributed to the precipitation event over southern Alberta. To quantify its impact, a simulation (CRCM5_dryair) with reduced initial atmospheric moisture content between 700 and
$925 \mathrm{hPa}$, i.e. specific humidity set to $0.001 \mathrm{~kg} \mathrm{~kg}^{-1}$ and condensed water set to zero, over Alberta, the Great Plains and the east Canadian Prairies (Fig. 2c) is compared to CRCM5_Ref. The temporal evolution of the region with decreased atmospheric moisture is followed for the 14-21 June period, and its impact on moisture fluxes and precipitation over southern Alberta is assessed.

\subsection{Impact of the state of the land surface on precipitation}

Milrad et al. (2015) suggested that ET from the land surface in regions to the east and southeast of Alberta acted as a moisture source. To study the impact of soil moisture in the Great Plains, the east Canadian Prairies and Alberta (Fig. 2c) on ET, atmospheric moisture and precipitation, several simulations are performed and compared to CRCM5_Ref. For each of these regions, two simulations are performed: one with initial soil moisture set to zero, in order to suppress ET, and the other with initial soil moisture set to saturation, in order to maximize ET. These simulations are referred to as CRCM5_SMdryGP and CRCM5 SMwetGP for the Great Plains, CRCM5_SMdryCP and 
CRCM5_SMwetCP for the east Canadian Prairies, and CRCM5_SMdryAB and CRCM5_SMwetAB for Alberta.

\subsection{Impact of the state of the land surface on streamflow}

The state of the land surface in an individual drainage basin plays a critical role in determining both the amplitude and the timing of streamflows in that basin. For example, rainon-snow events can lead to flash flooding, especially when soils at and downstream of the snow covered regions are saturated and/or frozen. To assess the role of the land surface in the BRB on the magnitude and timing of peak flow, two sensitivity experiments are performed and compared with CRCM5_Ref. In the first experiment (CRCM5_nosnow), snow is initialized to zero for the BRB. In the second experiment (CRCM5_unfrozen), in addition to no initial snow, the state of initial soil moisture is changed from frozen to liquid in the BRB.

\subsection{The Alberta flood from a climate perspective}

From the climate perspective, the frequency of occurrence of a precipitation event similar in magnitude to that of the Alberta flood event, defined as the cumulative precipitation over the 19-21 June period, is determined using extreme value analysis, for observed and modelled data for the 1981-2010 period. As the CaPA dataset is not available for this entire 30-year period, the ANUSPLIN dataset is used. The CRCM5 simulation considered (CRCM5_ERA) is driven by ERA-Interim and has a horizontal resolution of $0.11^{\circ}$. Extreme value analysis is performed on yearly MayJune maximum 3-day precipitation amounts for the 19812010 period, for both ANUSPLIN and CRCM5_ERA. The May-June transition months are considered since the chances of extreme flooding resulting from both meteorological and hydrological factors combined (e.g. heavy precipitation on snow or frozen and/or saturated soil) is the highest at this time of year. For the analysis, the Gumbel distribution is fitted by the method of L-moments to the 3-day precipitation extremes separately for each grid-cell in the province of Alberta and adjoining regions. The fit of the distribution is tested with the standard KolmogorovSmirnov goodness-of-fit (KS) test at the $5 \%$ significance level. The estimated return time of the 3-day precipitation event, defined as discussed above, is obtained from the fitted distribution and the resulting spatial pattern studied for ANUSPLIN and CRCM5_ERA.

The temporal evolution of the estimated return time of an event similar in magnitude to that of the Alberta flood event during the 21 st century is assessed using two CRCM5 transient climate change simulations corresponding to Representative Concentration Pathways RCP4.5 and RCP8.5 (van Vuuren et al. 2011). These simulations (CRCM5_CanESM2_4.5 and CRCM5_CanESM2_8.5) are available at $0.44^{\circ}$ resolution and are driven by the second generation Canadian Earth System Model (CanESM2) at the lateral boundaries. In this analysis, the Gumbel distribution is fitted to 30-year moving windows of extreme May-June 3-day precipitation amounts shifted in 5-year increments for grid cells located within the western BRB. The likelihood of future occurrences of a precipitation event similar in magnitude to that of the Alberta flood event in the western BRB is studied and discussed.

\subsection{Event attribution}

The influence of anthropogenic GHG emissions on the probability of occurrence of an event similar in magnitude to the Alberta flood event is explored. This is accomplished by comparing large ensembles of 1-year CRCM5 simulations, in GVAR configuration (Fig. 1c), for present-day and pre-industrial cases. As in Kay et al. (2011) and Christidis et al. (2013), the present-day and pre-industrial ensembles differ in their GHG concentrations, sea surface temperatures (SST), and sea-ice concentrations (SIC). In this study, the ensemble for the present-day case (CRCM5_Ind) uses GHG concentrations corresponding to the year 2013, while SST and SIC evolution is taken from ERA-Interim for 2013. Three ensembles for the pre-industrial case (CRCM5_preInd1, CRCM5_preInd2 and CRCM5_preInd3) are considered, where GHG concentrations correspond to their values for 1850, while SST and SIC correspond to pre-industrial conditions.

Pre-industrial SST is obtained by subtracting the SST change attributable to anthropogenic GHG emissions from the 2013 ERA-Interim SST. These attributable SST changes are calculated on a monthly basis from the allforcings and natural-forcings-only runs of three coupled Atmosphere-Ocean Global Climate Models from the fifth phase of the Coupled Model Intercomparison Project (CMIP5): CanESM2 for CRCM5_preInd1, GFDL-ESM2M (Geophysical Fluid Dynamics Laboratory) for CRCM5 preInd2 and GISS-E2-H (Goddard Institute for Space Studies) for CRCM5_preInd3. Pre-industrial SIC is then estimated using regression models relating SIC to SST (Pall et al. 2011), derived from ERA-Interim.

Each ensemble consists of 1000 members, initialized $1 \mathrm{~h}$ apart between 0800 UTC 20 November and 2300 UTC 31 December 2012. Initial conditions are taken from respective spin-ups, which start in early 2012, one for the presentday scenario and one for each pre-industrial scenario. The analysis focuses on comparing the present-day and preindustrial distributions of May-June maximum 3-day and 


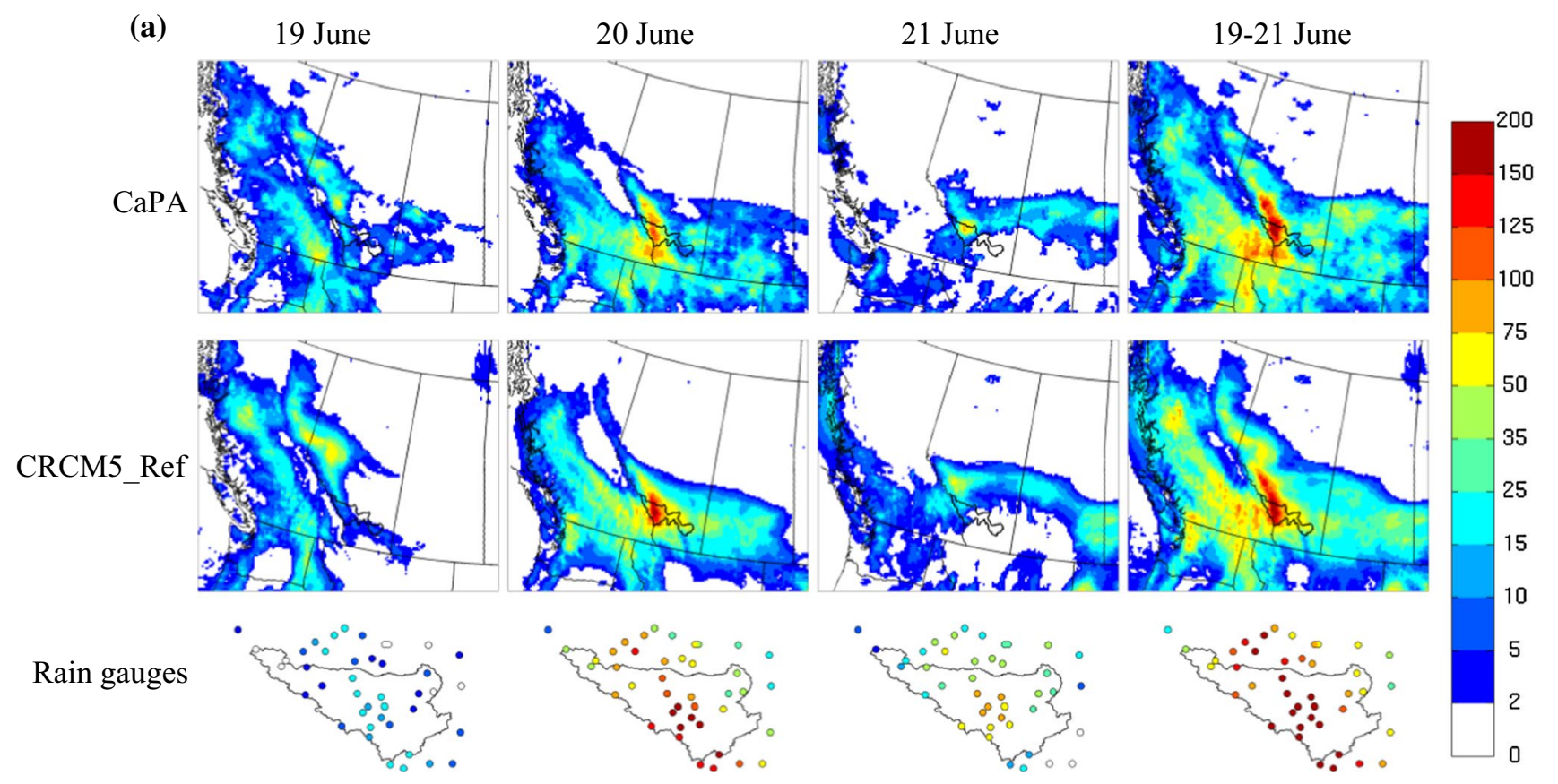

(b)

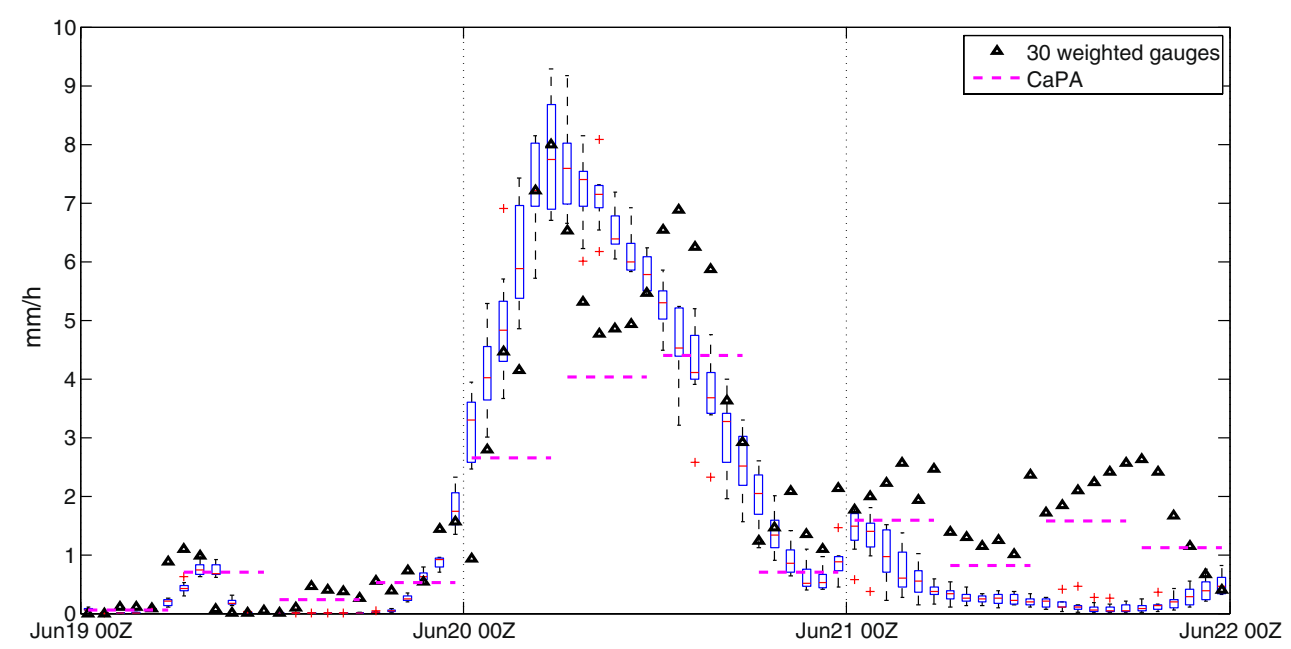

Fig. 3 a Spatial distribution of daily and 3-day precipitation ( $\mathrm{mm}$ ) during 19-21 June, as estimated by CaPA, simulated by CRCM5_ Ref and measured by rain gauges (limited to the western Bow River basin). b Evolution of hourly rainfall rates averaged over the western

1-day precipitation and surface runoff values over different flood-affected regions and average ET over the Great Plains.

\section{Meteorological and hydrological evolution, from observations and CRCM5}

The heavy precipitation event during 19-21 June 2013, discussed above, affected southern Alberta and adjoining regions. The heaviest precipitation during this period fell
Bow River basin during 19-21 June, as simulated by the members of CRCM5_Ref (blue boxplot), measured by rain gauges (black triangles) and estimated by CaPA (magenta dashed lines, 6-hourly)

over the foothills of the Canadian Rockies, including the western part of the BRB. CRCM5_Ref reproduces reasonably well the spatial pattern of daily and 3-day precipitation amounts estimated by CaPA and rain gauges in the western BRB (Fig. 3a). On 19 June, the precipitation pattern includes two bands of heavy precipitation, one over western Alberta and the other over British Columbia, which are well captured by the model. On 20 June, the intense precipitation west of Calgary is well simulated by CRCM5 Ref, but some overestimation is evident over southeastern Alberta and southern Saskatchewan, as a result of the 

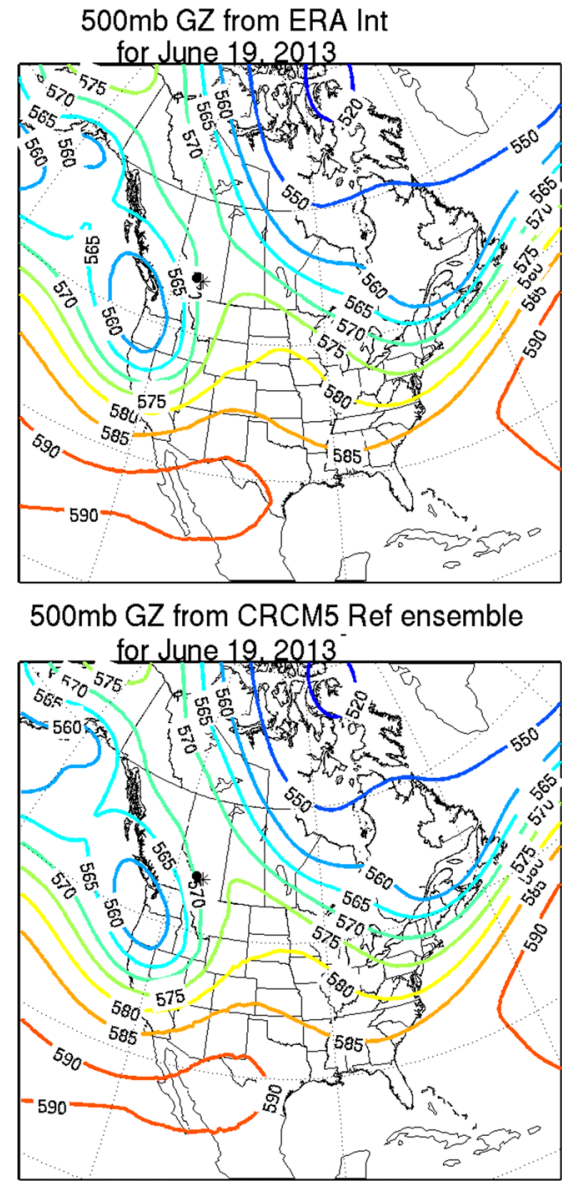

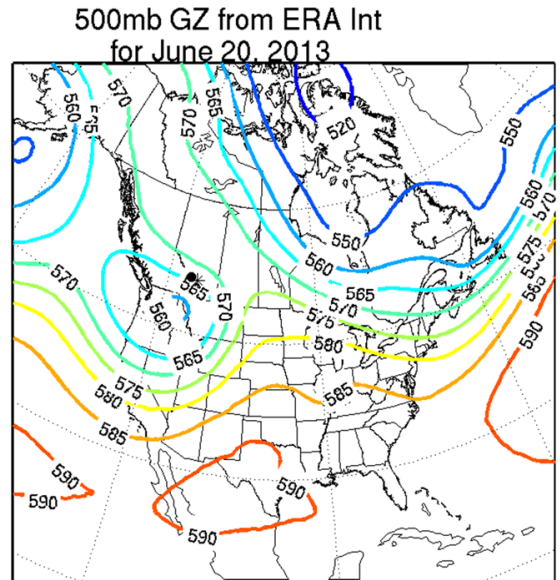

$500 \mathrm{mb}$ GZ from CRCM5 Ref ensemble for June 20, 2013

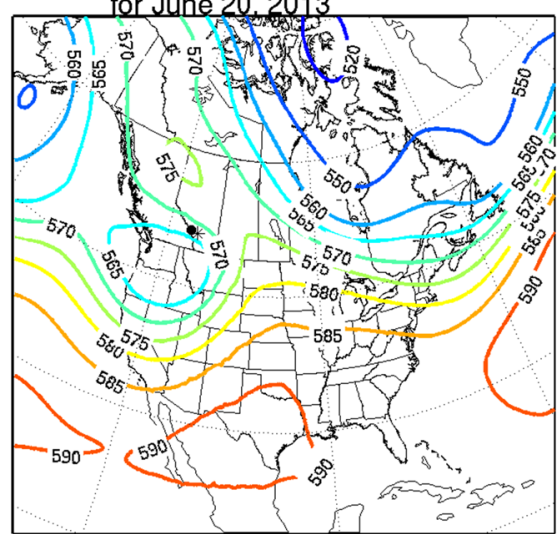

$500 \mathrm{mb}$ GZ from ERA Int

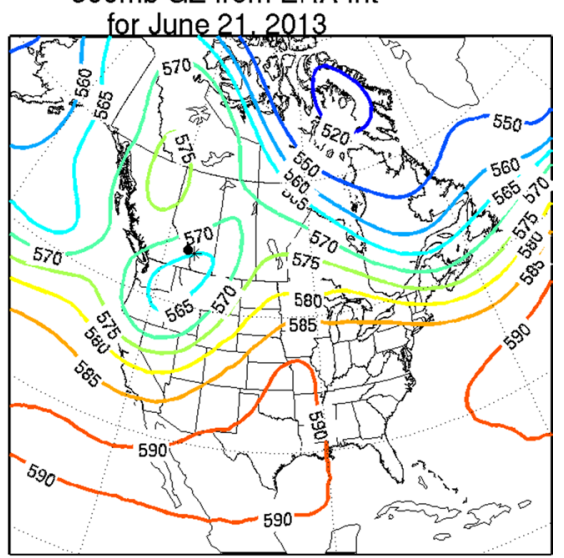

$500 \mathrm{mb}$ GZ from CRCM5 Ref ensemble for June 212013

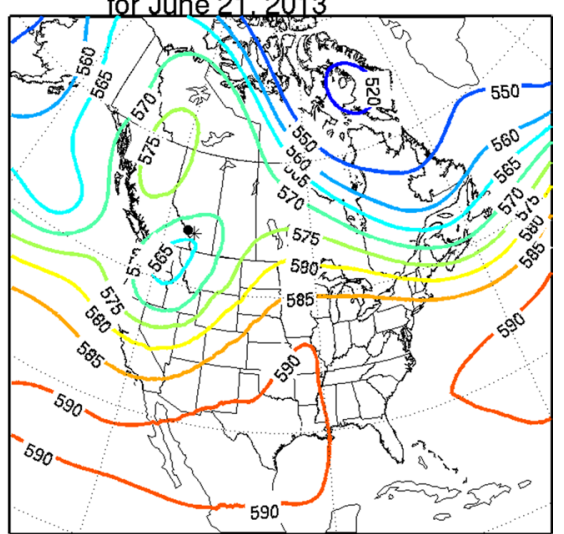

Fig. 4 Geopotential height (GZ) at 500 hPa for 19 June (left column), 20 June (middle column) and 21 June (right column), from ERA-Interim (top row) and the ensemble mean from CRCM5_Ref (bottom row)

northward displacement of the heavy precipitation band with respect to CaPA. On 21 June, the simulated precipitation over southwestern Alberta is again slightly displaced towards the north, resulting in underestimation of the precipitation over the BRB.

Over the western BRB, the precipitation event started in the evening hours of 19 June and quickly gained intensity, with the heaviest precipitation lasting until around noon on 20 June (local time, UTC-6), followed by moderate precipitation that lasted until the evening hours of 21 June (Fig. 3b). CRCM5_Ref captures the start of the event well, in addition to its peak intensity over this region (close to $10 \mathrm{~mm} \mathrm{~h}^{-1}$ ). However, it does not reproduce the continuing precipitation on 21 June due to the northward displacement of the precipitation band.

On the synoptic scale (Milrad et al. 2015), from 15-17 June, the presence of a mid-tropospheric cyclonic disturbance near the coast of Washington and British Columbia, along with a strong ridge to its north, completed a Rex block (Rex 1950), characterized by north to south airflow and little eastward progression of these systems, resulting in stagnant weather conditions. This blocking pattern broke down on 18 June, allowing the disturbance to progress eastward and make landfall on 19 June. In response to this disturbance, a strong lee surface cyclone developed on 19 June, becoming established just to the south of the heavy precipitation region on 20 June, when its circulation transported moist air from the Great Plains towards the eastern slopes of the Canadian Rockies, producing the heavy precipitation event. A ridge over northern Alberta slowed the progression of this cyclone by creating a new Rex block, resulting in continued moisture transport towards southern Alberta on 21 June and therefore, further precipitation.

CRCM5_Ref reproduces well the evolution of the $500 \mathrm{hPa}$ geopotential height seen in the ERA-Interim reanalysis (Fig. 4), which is expected due to the large-scale constraints imposed via spectral nudging. In particular, the low-pressure system just to the south of the BRB on June 20 , responsible for the advection of moisture-laden air towards the affected region, and the ridge intensifying to its north on 21 June, responsible for slowing down the movement of this cyclone, are well reproduced. The evolution of 


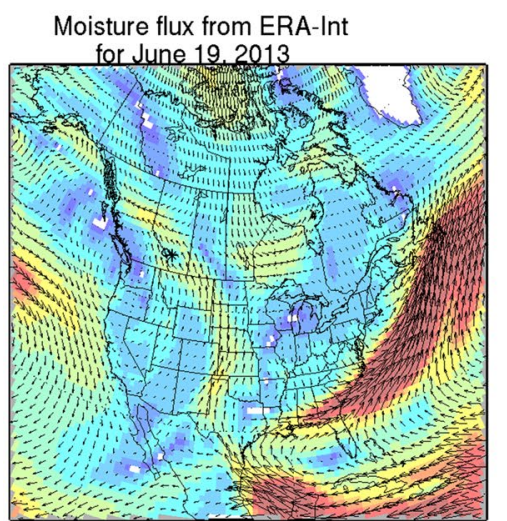

Moisture flux from CRCM5 Ref ensemble

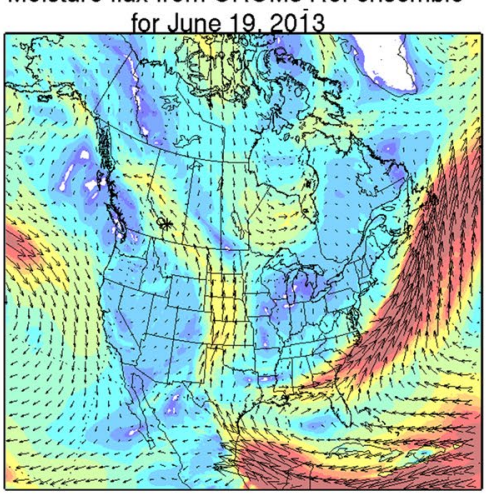

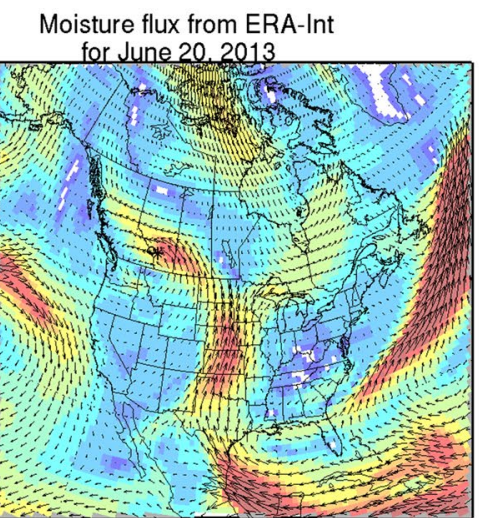

Moisture flux from CRCM5 Ref ensemble

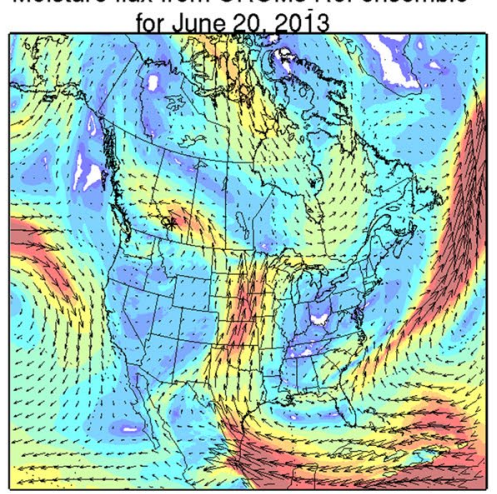

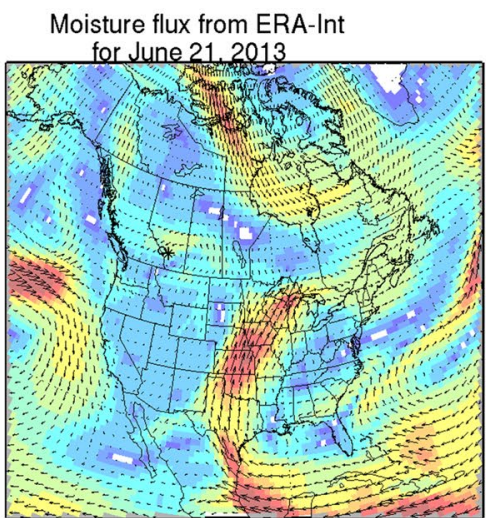

$\mathrm{kg} \mathrm{m}^{-1} \mathrm{~s}^{-1}$

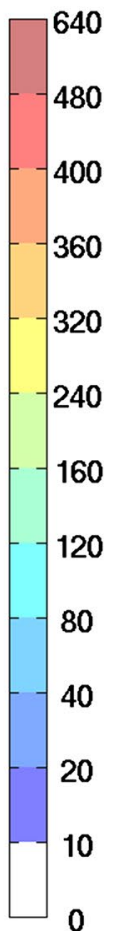

Fig. 5 Vertically integrated moisture flux for 19 June (left column), 20 June (middle column) and 21 June (right column), from ERA-Interim (top row) and the ensemble mean from CRCM5_Ref (bottom row)

the 200 and 700-hPa winds is also well captured (Figures S1, S2). The vertically integrated moisture flux (Fig. 5) is generally well represented, showing strong advection of moisture from the Prairies and Great Plains towards southwestern Alberta throughout the event, with the most prominent difference being the northward displacement of the core of high moisture flux values over southern Alberta on 21 June in CRCM5_Ref. This displacement is associated with the northward displacement of the precipitation band (Fig. 3a) and the underestimation of rainfall in the western BRB on this last day of the event (Fig. 3b).

The processes controlling the vertically integrated water vapour content (IWV) during the 19-21 June period are investigated using the CRCM5_Ref ensemble (Fig. 6). The results of this analysis show that strong positive water vapour advection occurred over southwestern Alberta during the event (upper left panel). This strong advection is balanced by large-scale condensation (lower right panel), with convection playing a minor role (lower left panel), which is consistent with low CAPE (Milrad et al. 2015) and the lack of lightning over regions receiving heavy precipitation (Pomeroy et al. 2016). The location and the magnitude of large-scale condensation are very similar to those of the modelled rainfall (Fig. 3a), confirming that large-scale processes controlled this precipitation event.

In response to the heavy precipitation event over the western BRB (Fig. 3b), the observed hydrograph for the Bow River at Banff (left panel of Fig. 7) shows an increase in streamflow from around $150 \mathrm{~m}^{3} \mathrm{~s}^{-1}$ on 19 June to over $400 \mathrm{~m}^{3} \mathrm{~s}^{-1}$ at the peak discharge on 21 June. The hydrographs for the individual CRCM5_Ref ensemble members correctly reproduce the observed streamflows before the event, and they all exhibit peak streamflow on 21 June, which agrees well with the observed streamflows. However, there is large spread between the members of CRCM5_Ref in the simulated peak streamflow as a result of important spread in simulated precipitation upstream of Banff on 20 June.

For the Bow River at Calgary (right panel of Fig. 7), the observed hydrograph shows an increase in streamflow from around $200 \mathrm{~m}^{3} \mathrm{~s}^{-1}$ on 19 June to over $1700 \mathrm{~m}^{3} \mathrm{~s}^{-1}$ at the peak discharge on 21 June. Though the timing of the peak flow is well captured by the CRCM5_Ref ensemble, the simulated peak discharge is larger than observed, and is close to $2500 \mathrm{~m}^{3} \mathrm{~s}^{-1}$. When comparing observed and modelled 
Fig. 6 Average contributions of advection, vertical diffusion, convection and large-scale condensation to the vertically integrated water vapour content (IWV), during the 19-21 June period, from the CRCM5_Ref ensemble
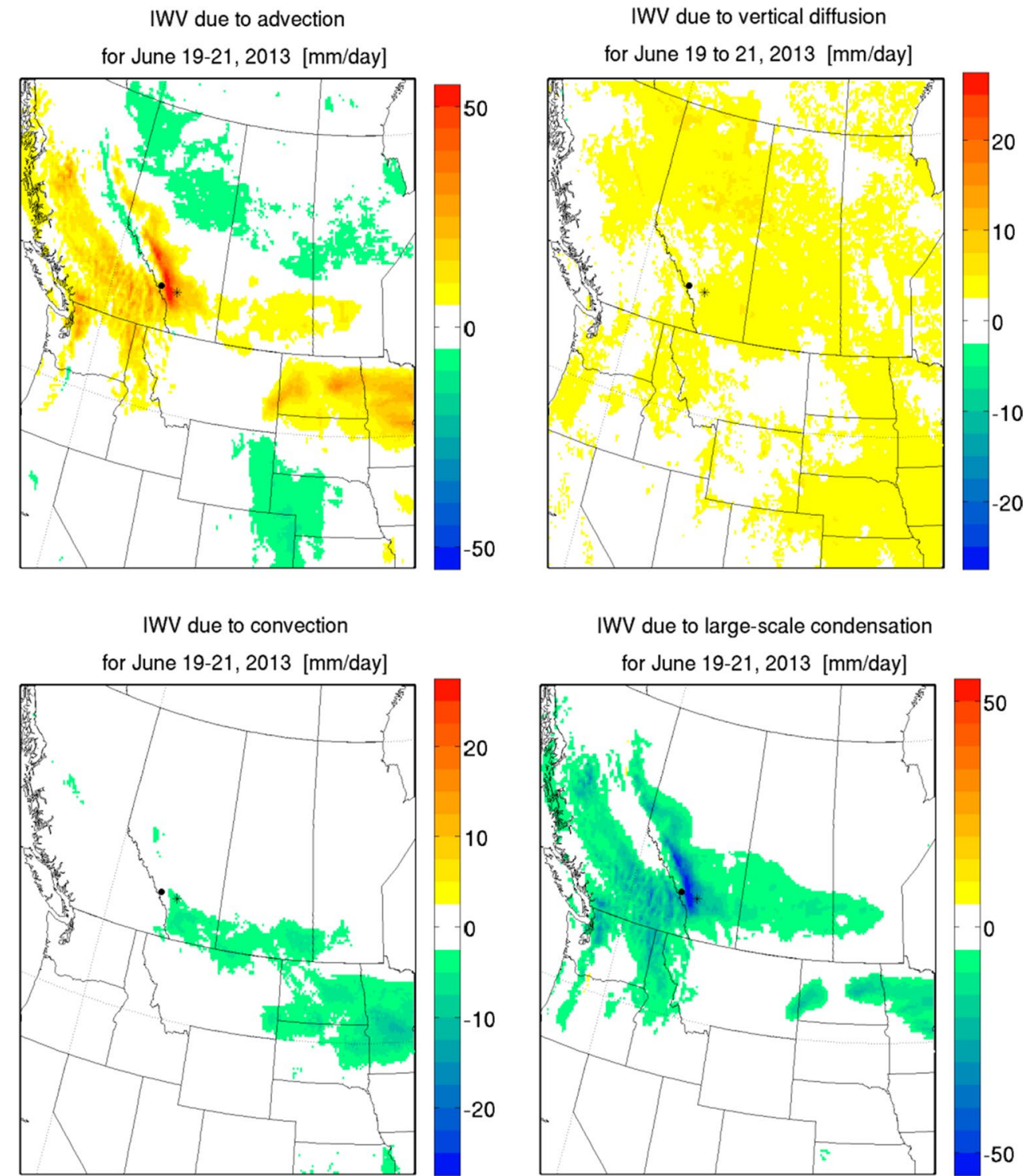

IWV due to large-scale condensation

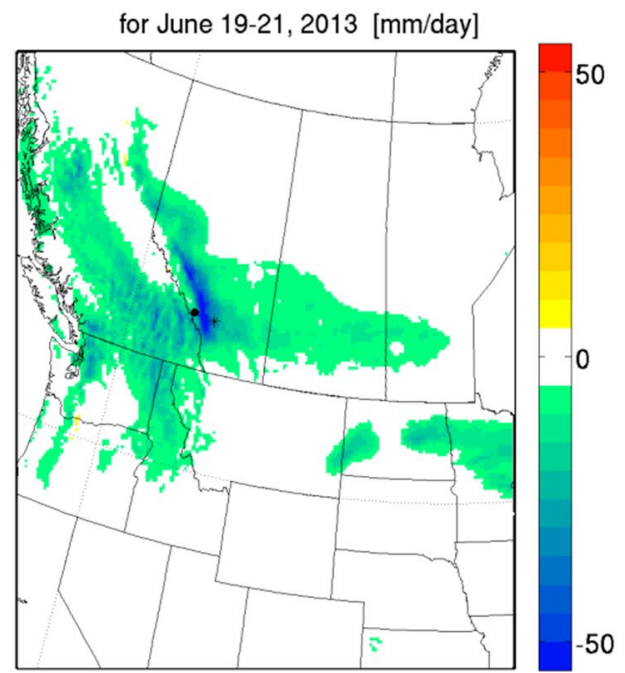

streamflows at Calgary, it is important to consider that the flow of the Bow River after Banff is regulated by several reservoirs before arriving at Calgary (Pomeroy et al. 2016), that the observed flow is not naturalized and that the simulated flow does not take this regulation into account; therefore overestimation of the modelled flow is expected. In addition, the intensity of the precipitation upstream of Calgary on 20 June is slightly overestimated by CRCM5_Ref (Fig. 3).

\section{Investigation from a weather perspective}

This section discusses the contribution of orography and diverse moisture sources to the meteorological flood, as well as the contribution of snowmelt and soil moisture phase to the hydrological flood.

\subsection{Impact of orography}

A $75 \%$ reduction in the terrain elevation above $1200 \mathrm{~m}$ of the southern Canadian Rockies results in significantly reduced precipitation in CRCM5_Oro over the eastern foothills, including most of the western BRB, with the 19-21 June precipitation totals reduced by up to $100 \mathrm{~mm}$ (Fig. 8a). This is consistent with the reduced orographic forcing on the moisture-laden air on the lee side of the Rockies. In contrast, the 19-21 June precipitation totals over eastern British Columbia increase by around $20 \mathrm{~mm}$, as the rain shadow effect of the Rockies is reduced.

The temporal evolution of precipitation in the western BRB from the CRCM5_Oro simulation closely resembles the CRCM5_Ref ensemble (Fig. 8b) during the early hours of the heaviest precipitation event, suggesting that the onset 

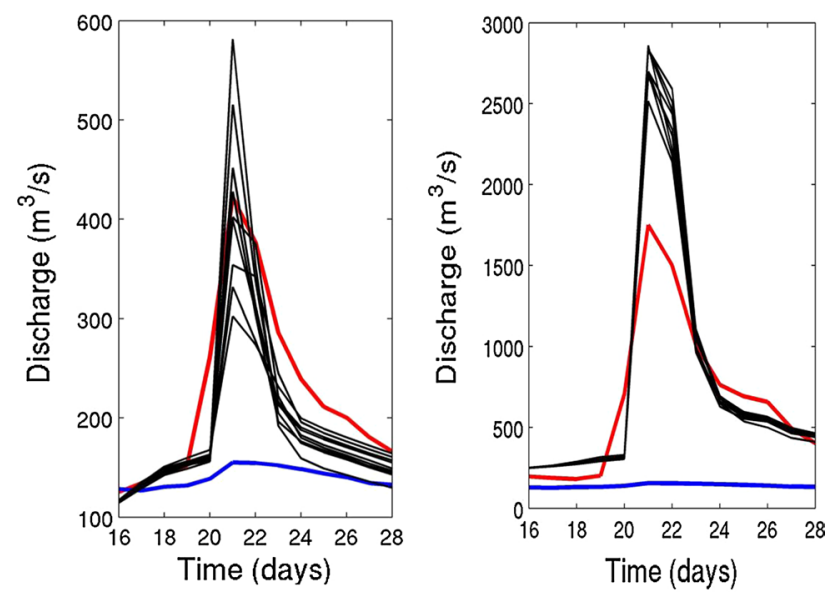

Fig. 7 Evolution of climatological (blue), observed (red) and simulated (black) streamflows during June 2013 in the Bow River at Banff (left) and in the Bow River at Calgary (right). Each black line represents a different member of the CRCM5_Ref ensemble of precipitation was not strongly controlled by orographic lifting. Similarly, Milrad et al. (2015) found that quasigeostrophic ascent was dominant during the start of the event. However, during the remainder of the precipitation event on 20 June, including the most intense rainfall rates, orographic lifting played a major role, with CRCM5_Oro producing a 3-day total of $80 \mathrm{~mm}$, while the members of CRCM5_Ref range from 110 to $125 \mathrm{~mm}$, a $30 \%$ reduction in rainfall. While these results highlight the possible importance of orographic forcing during heavy precipitation events, they do not provide insight into the causing factors behind the June 2013 event. In contrast, the sensitivity studies discussed below explore the importance of initial conditions and have the potential to improve the understanding of the causes of such weather events.
Fig. 8 a Differences in 19-21 June precipitation $(\mathrm{mm})$ between the CRCM5_Oro simulation and the CRCM5_Ref ensemble. Differences are between CRCM5_Oro and the limit of the range given by the CRCM5_Ref members for each grid cell. If the experiment is within this range, no shading is applied. b Evolution of hourly rainfall rates averaged over the western Bow River basin during 19-21 June, from the members of CRCM5_Ref (boxplot, average in black) and the CRCM5_ Oro simulation (green) (a)

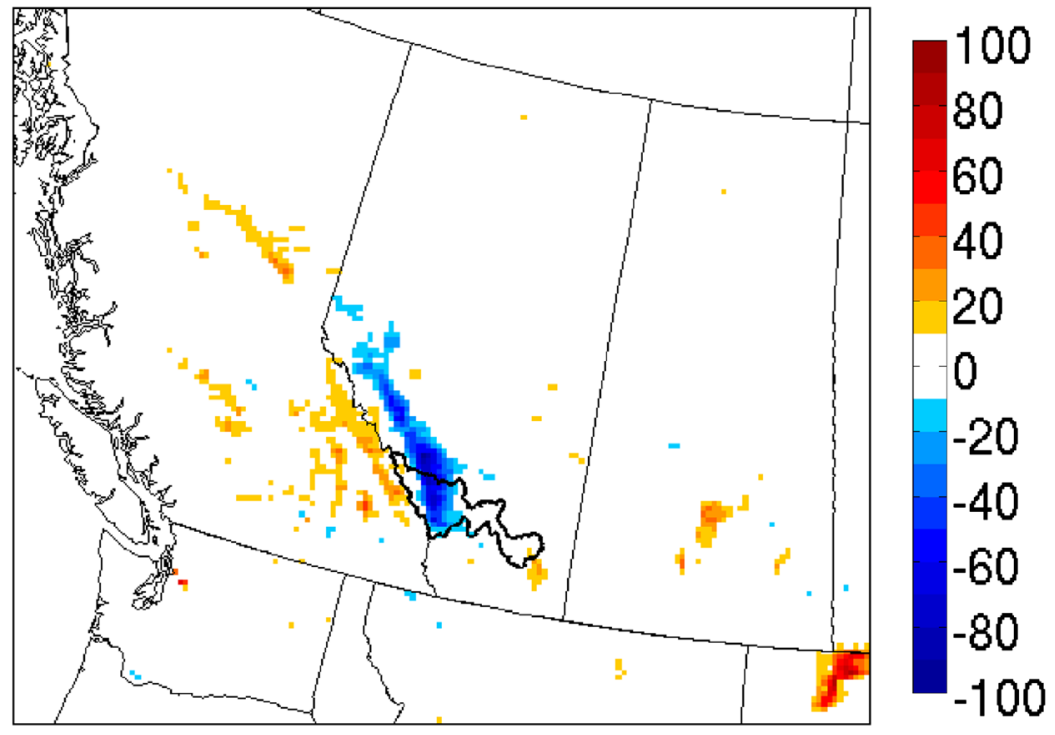

(b)

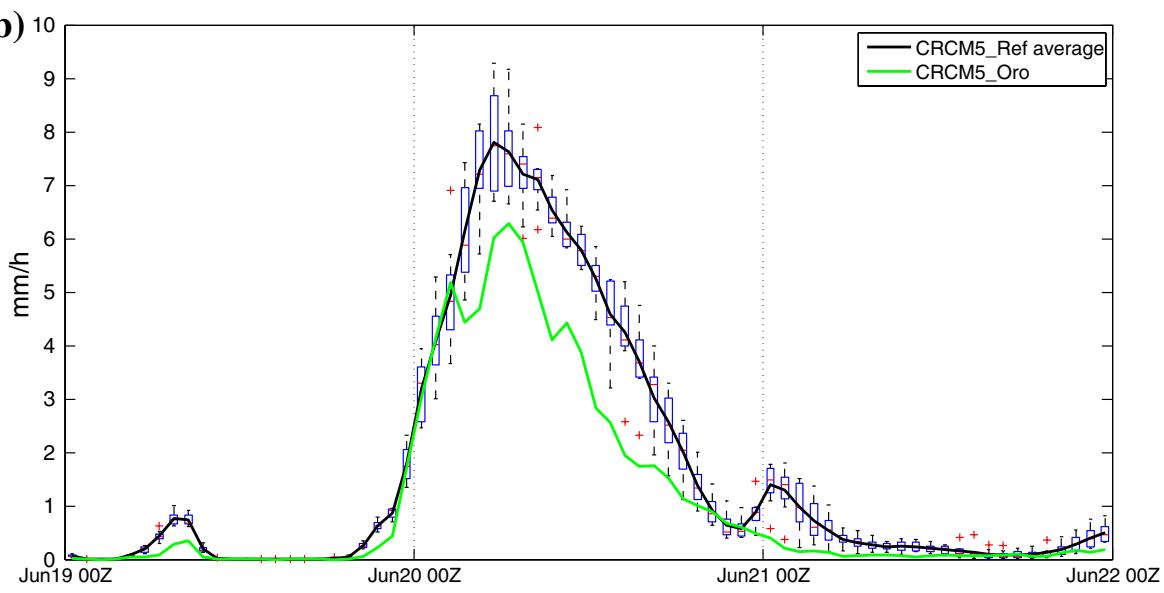


(a) Evapotranspiration

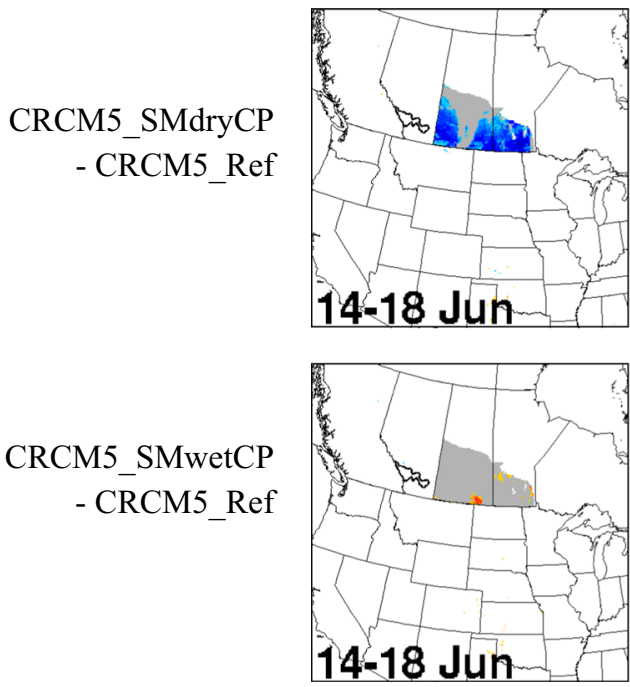

(b) Integrated water vapour

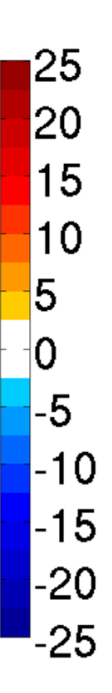

(c) Precipitation

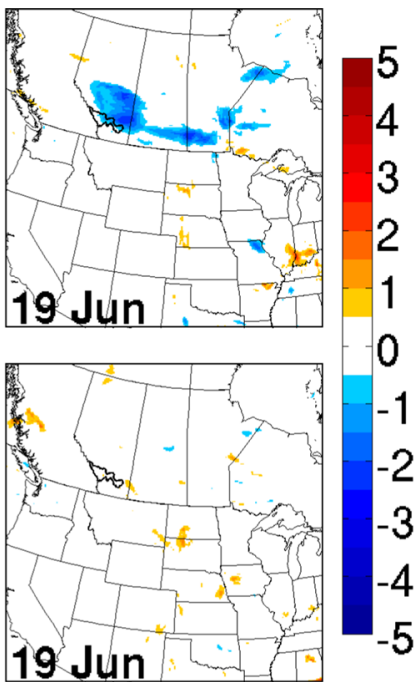

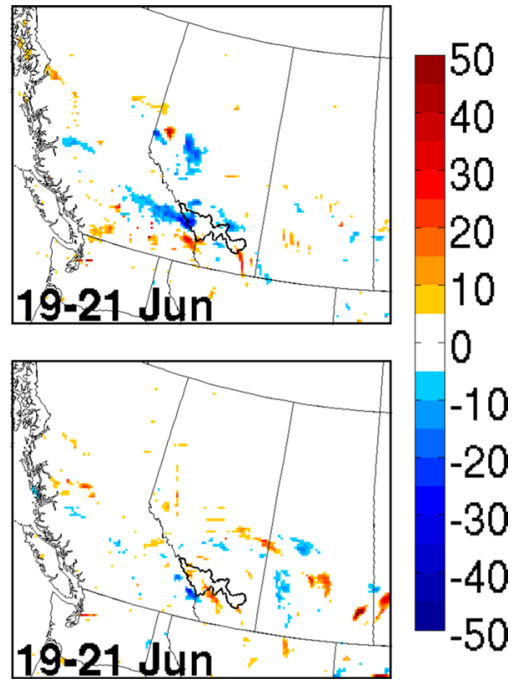

(d)

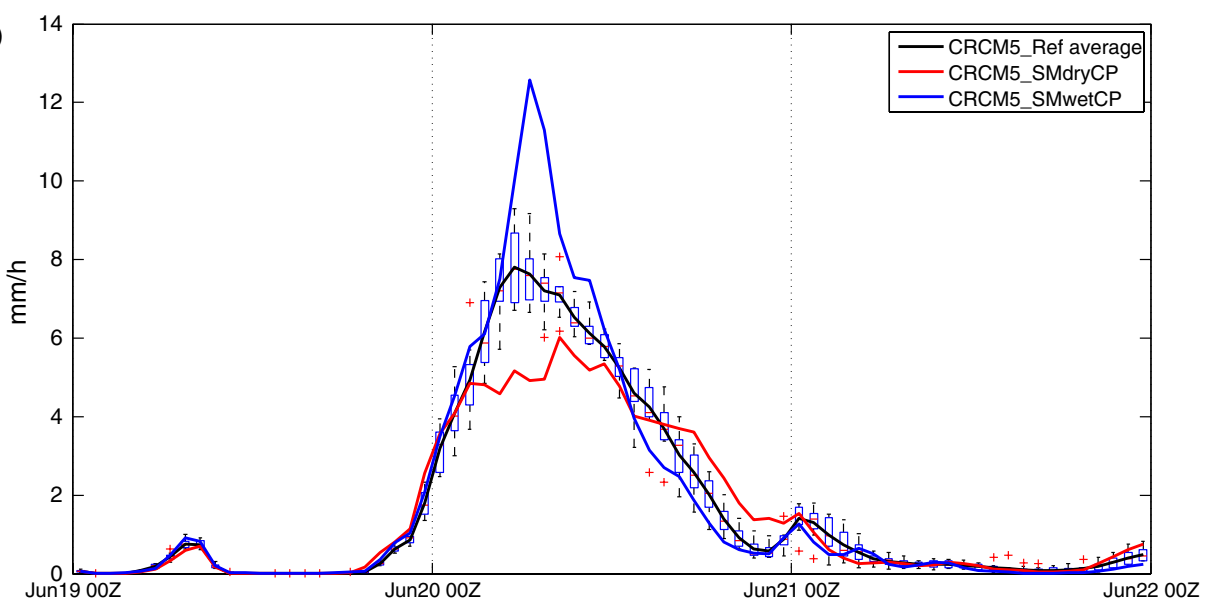

Fig. 9 Differences between the CRCM5_SMdryCP simulation and the CRCM5_Ref ensemble (top row) and differences between the CRCM5_SMwetCP simulation and the CRCM5_Ref ensemble (bottom row), in: a total evapotranspiration for 14-18 June (mm), with grey background over the region where initial soil moisture was altered, b integrated water vapour $(\mathrm{mm})$ on 19 June, $\mathbf{c}$ total precipitation (mm) for 19-21 June. Differences are between the experi-

\subsection{Impact of antecedent atmospheric moisture}

The impact of removing low-level atmospheric moisture over Alberta, the Great Plains and the east Canadian Prairies at 0000 UTC 14 June (CRCM5_dryair) is weak over the BRB, mainly due to strong westerly winds (Figure S3). However, precipitation associated to this moisture is suppressed on 14 June, resulting in lower soil moisture over parts of the Great Plains and the Prairies, hence reduced ET and slightly less precipitation during 19-21 June over parts of southern Alberta. ment and the limit of the range given by the CRCM5_Ref members for each grid cell. If the experiment is within this range, no shading is applied. d Evolution of hourly rainfall rates averaged over the western Bow River basin during 19-21 June, from the members of CRCM5_Ref (boxplot, average in black), the CRCM5_SMdryCP simulation (red) and the CRCM5_SMwetCP simulation (blue)

\subsection{Impact of the state of the land surface on precipitation}

The sensitivity of CRCM5 modelled precipitation to the initial state of soil moisture in the Great Plains and the east Canadian Prairies is analyzed, by linking differences in soil moisture to differences in ET, which directly influences the atmospheric water vapour content and ultimately has an effect on the location and intensity of rainfall. The effects of soil moisture modification in Alberta (Figure S4) on precipitation over the BRB are weak, implying that the role of local ET was minor during the flood. However, 
(a) Evapotranspiration

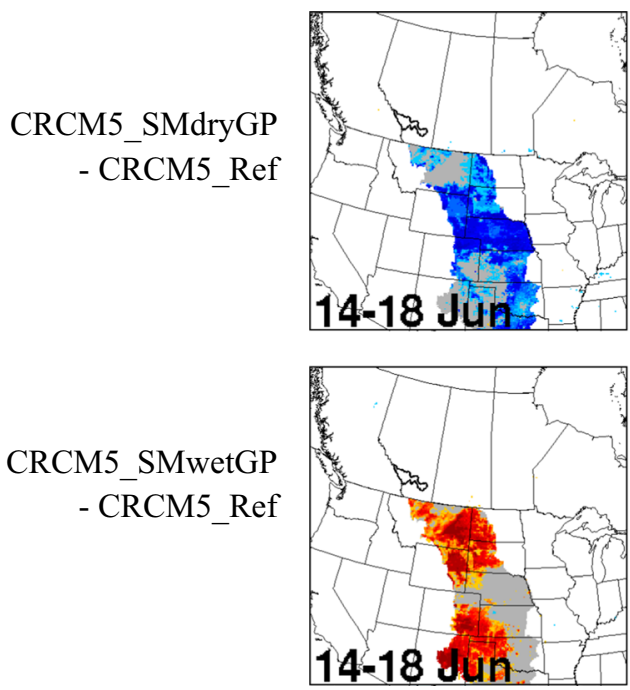

(b) Integrated water vapour
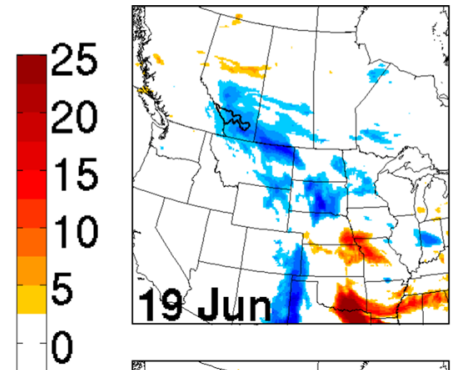
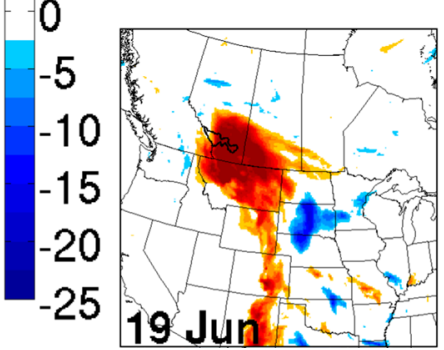

(c) Precipitation

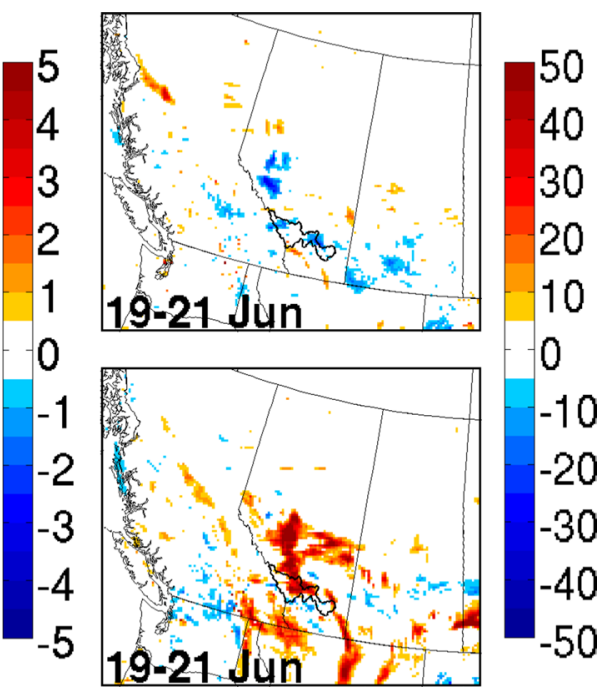

(d)

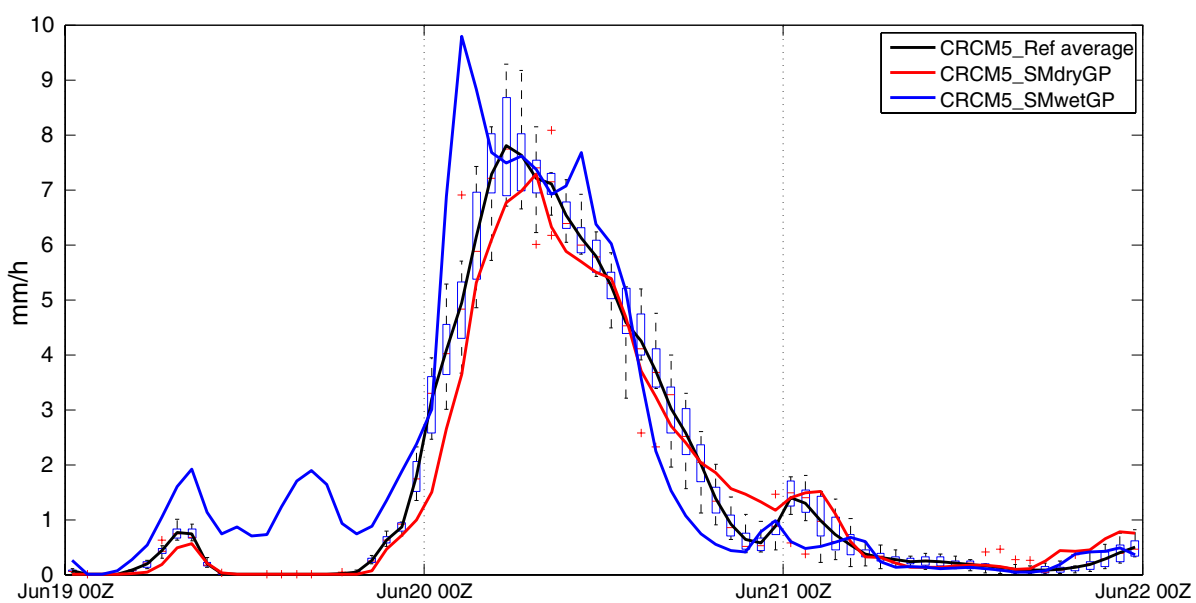

Fig. 10 Differences between the CRCM5_SMdryGP simulation and the CRCM5_Ref ensemble (top row) and differences between the CRCM5_SMwetGP simulation and the CRCM5_Ref ensemble (bottom row), in: a total evapotranspiration for 14-18 June (mm), with grey background over the region where initial soil moisture was altered, b integrated water vapour $(\mathrm{mm})$ on 19 June, c total precipitation (mm) for 19-21 June. Differences are between the experi- ment and the limit of the range given by the CRCM5_Ref members for each grid cell. If the experiment is within this range, no shading is applied. d Evolution of hourly rainfall rates averaged over the western Bow River basin during 19-21 June, from the members of CRCM5_Ref (boxplot, average in black), the CRCM5_SMdryGP simulation (red) and the CRCM5_SMwetGP simulation (blue)

regions to the north and west (Fig. 9c, upper panel). The temporal evolution (Fig. 9d) is even more explicit since it shows that, over the western BRB, the CRCM5_SMdryCP simulation has less intense rainfall rates during the peak of the event than any member of the CRCM5_Ref ensemble, though slightly heavier rainfall occurs during the last hours of 20 June.

CRCM5_SMwetCP has a small effect on ET, mostly concentrated over southeastern Saskatchewan, as most of the Prairies are close to saturation in CRCM5_Ref and/ or receive rainfall from an event on 14-16 June (Fig. 9a, lower panel). While the differences in ET and IWV on 19 These anomalies have important effects on precipitation 
June (Fig. 9b, lower panel) are small, some regions of the BRB receive more rainfall in CRCM5_SMwetCP during the event (Fig. 9c, lower panel). The effect on the temporal evolution of the event in the western BRB is reversed from CRCM5_SMdryCP, with heavier precipitation during the peak of the event, and slightly less intense rainfall during the second half of 20 June (Fig. 9d).

CRCM5_SMdryGP has a widespread effect on ET over the Great Plains in the days leading to the event (Fig. 10a, upper panel). By 19 June, a large region of negative IWV anomalies has established over southern Alberta, extending to the southeast (Fig. 10b, upper panel). In response, precipitation during the event is reduced over some areas of southern Alberta and southern Saskatchewan (Fig. 10c, upper panel). However, the temporal evolution of the event over the western BRB remains mostly unchanged, with the most prominent feature being slight reductions in rainfall rate during the first hours of the event on 20 June (Fig. 10d).

CRCM5_SMwetGP has a very strong effect on ET over the Great Plains (Fig. 10a, upper panel). By 19 June, the enhanced ET creates very strong $(>5 \mathrm{~mm})$ positive IWV anomalies over southern Alberta and extending to the southeast (Fig. 10b, lower panel). The presence of these anomalies is associated with heavier rainfall during the event over southern Alberta, with large regions receiving from 10 to $50 \mathrm{~mm}$ more rainfall, including a large part of the BRB (Fig. 10c, lower panel). The temporal evolution of the event over the western BRB is modified by the addition of pulses of moderate rainfall on 19 June, with the peak rainfall rate arriving earlier and stronger than in CRCM5_Ref (Fig. 10d). The rainfall rates decrease sharply during the second half of 20 June in CRCM5_SMwetGP, but nonetheless the total precipitation for the 3-day event exceeds the CRCM5_Ref ensemble by around $20 \%$.

\subsection{Impact of the state of the land surface on streamflow}

In order to determine the role played by the state of the land surface on the amplitude and timing of streamflows, the hydrographs from the members of CRCM5_Ref are compared to those of CRCM5_nosnow and CRCM5_unfrozen, for the Bow River at Calgary. Initialization with zero snow (0000 UTC 14 June) in the two latter simulations results in a large decrease of the peak streamflow and also a 1-day lag in reaching the peak, as a result of decreased flow velocity (Fig. 11). The difference between CRCM5_Ref and CRCM5_nosnow cannot be solely attributed to the presence or absence of snow over the BRB, as in the absence of snow insulation (in CRCM5_nosnow) heat from the surface thaws the upper soil layers and thereby increases infiltration at the surface on 20 June. The absence of frozen

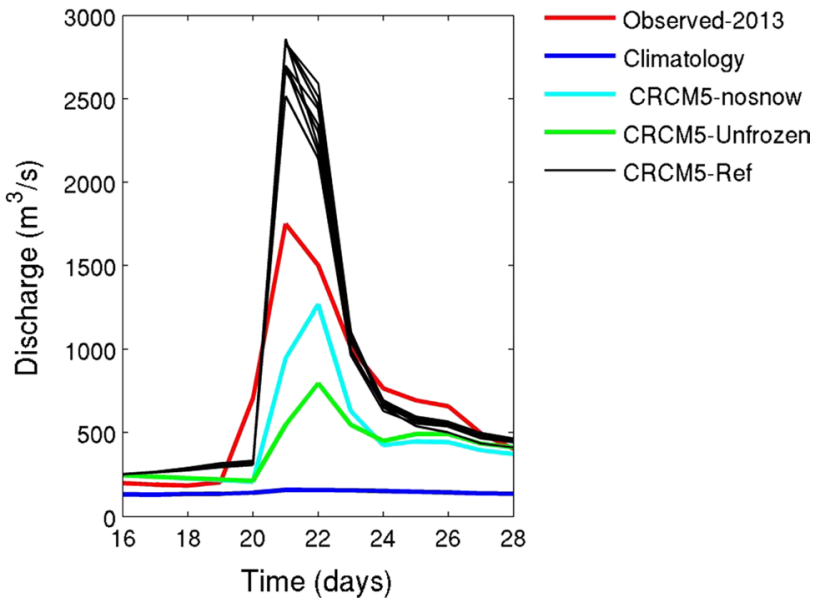

Fig. 11 Sensitivity of the simulated streamflows in the Bow River at Calgary to the presence of snow (CRCM5_nosnow) and frozen soil (CRCM5_unfrozen). Each black line represents a different member of CRCM5_Ref

water in the soil (in CRCM5_unfrozen) further increases infiltration, leading to an even larger reduction in the peak discharge.

As the contribution of snowmelt to surface runoff during the precipitation event cannot be determined using only the CRCM5_nosnow simulation, a further assessment is performed by comparing the modelled snowmelt on 20 June to the modelled surface runoff and precipitation for the same day, for each member of CRCM5_Ref. This assessment reveals that the average modelled snowmelt for the grid cells upstream of Calgary is around $25-30 \mathrm{~mm}$ on 20 June, while precipitation amounts range from 90 to $100 \mathrm{~mm}$, meaning that around 20 to $25 \%$ of surface runoff results from snowmelt. Assessment of the ratio between surface runoff and water available at the soil surface shows that approximately $60 \%$ of the available water in CRCM5_Ref infiltrates, while in CRCM5_nosnow this value increases to $80 \%$ and in CRCM5_unfrozen to $90 \%$, as the permeability of the soil is higher in those two cases due to the reduced frozen water content.

\section{Investigation from a climate perspective}

The return times of the 3-day (19-21 June) precipitation amount in present-day climate (i.e. 1981-2010) are estimated for each grid cell using ANUSPLIN and CRCM5 ERA (Fig. 12a). It must be noted that the 3-day precipitation amount considered for CRCM5_ERA is the ensemble mean of CRCM5_Ref (Fig. 3a). For the ANUSPLIN-based analysis (left panel), the return time is estimated to exceed 50 years for most of the western BRB, with similarly long return times extending to the north and to the southwest. 
(a)

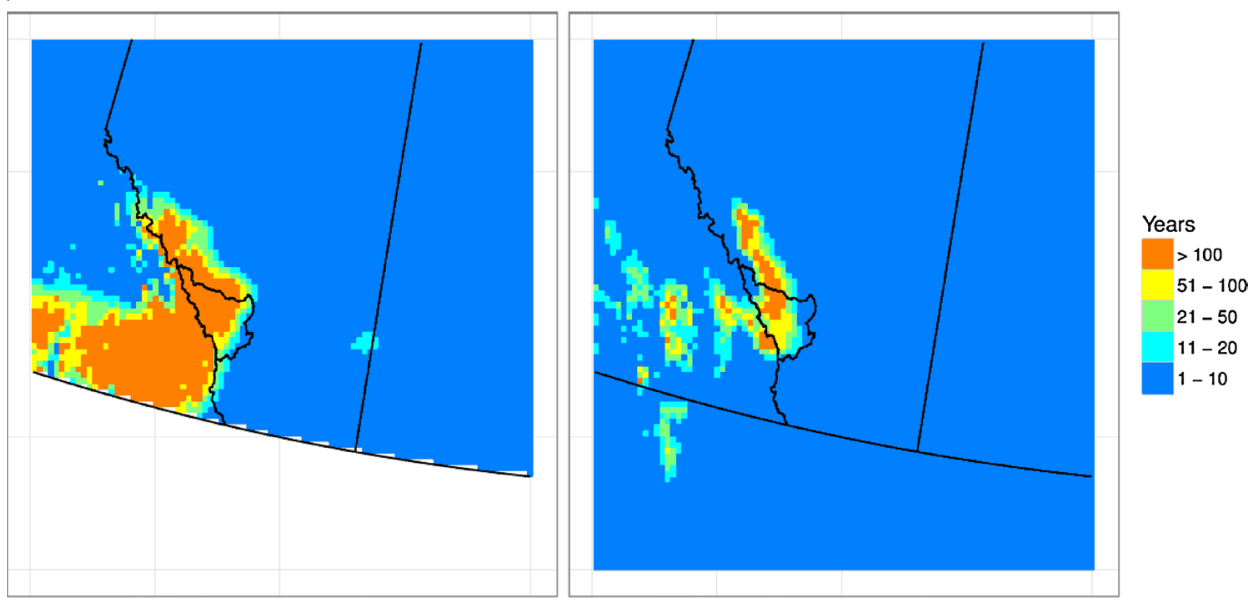

(b)

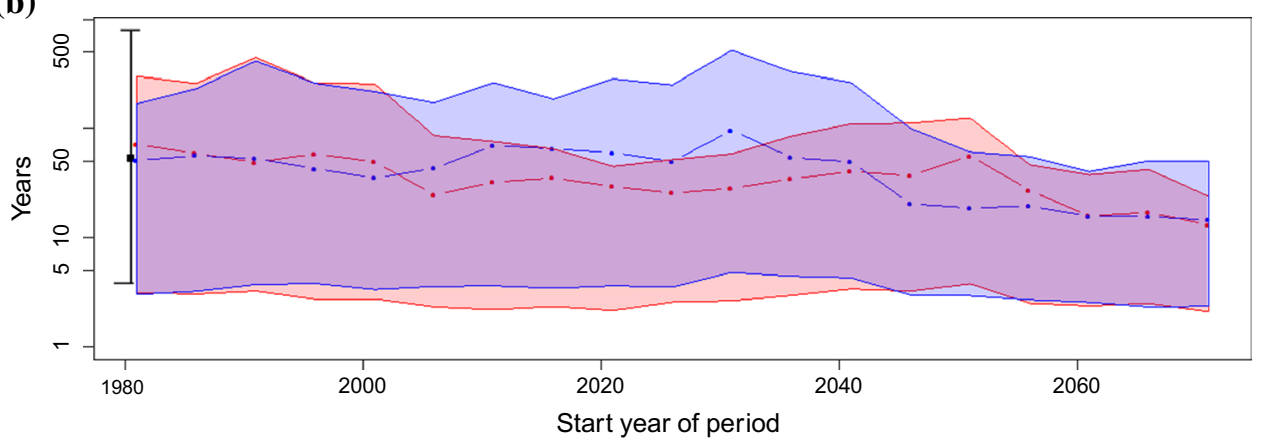

Fig. 12 a Return times of the 19-21 June precipitation event over southern Alberta and adjoining regions, based on 1981-2010 climatology, from ANUSPLIN (left) and CRCM5_ERA (right). b Return times of the 19-21 June precipitation event over the western Bow

For the CRCM5_ERA-based analysis (right panel), the return time exceeds 50 years for about half of the grid cells of the western BRB, with long return times also observed to the north and to the southwest of this region. The agreement between ANUSPLIN and CRCM5_ERA is high at the eastern boundary of the region encompassing the high return times. The large differences over the westernmost $\mathrm{BRB}$ and southern British Columbia originate from the handling of the orographic rain shadow, as CRCM5_ERA is able to directly simulate the effects of orography on precipitation, while ANUSPLIN relies on interpolation between sparse rain gauges, which results in higher precipitation amounts and less spatial variation when compared to CRCM5_ERA or CaPA (not shown). The long return times obtained over the western BRB are consistent with the record-breaking rainfall and streamflows observed in this region.

The projected evolution of the return times during the 21 st century for the western BRB for 3-day precipitation of similar magnitude as the 19-21 June rainfall, from the
River basin and their $90 \%$ confidence intervals, based on 30-year periods starting on the labelled date, for CRCM5_ERA (black, single point at 1981), CRCM5_CanESM2_4.5 (blue) and CRCM5_ CanESM2_8.5 (red)

CRCM5 transient climate change simulations corresponding to RCP4.5 and RCP8.5 (CRCM5_CanESM2_4.5 and CRCM5_CanESM2_8.5) is shown in Fig. 12b. In present-day climate, the best estimate of the return time appears to be close to 60 years. By the end of the century (2070-2100), the return time is projected to decline to approximately 20 years under these realizations of the RCP4.5 and RCP8.5 scenarios. Although the evolution of the return time differs considerably between the scenarios and the influence of interdecadal variability on extremes is evident, both project an overall increase in the occurrence of extreme precipitation events in the western BRB, which is consistent with the projected increases in atmospheric moisture and energy.

\subsection{Event attribution}

The frequency distributions of May-June average ET, maximum 1-day and 3-day precipitation and runoff are compared between present-day and pre-industrial climates, over 

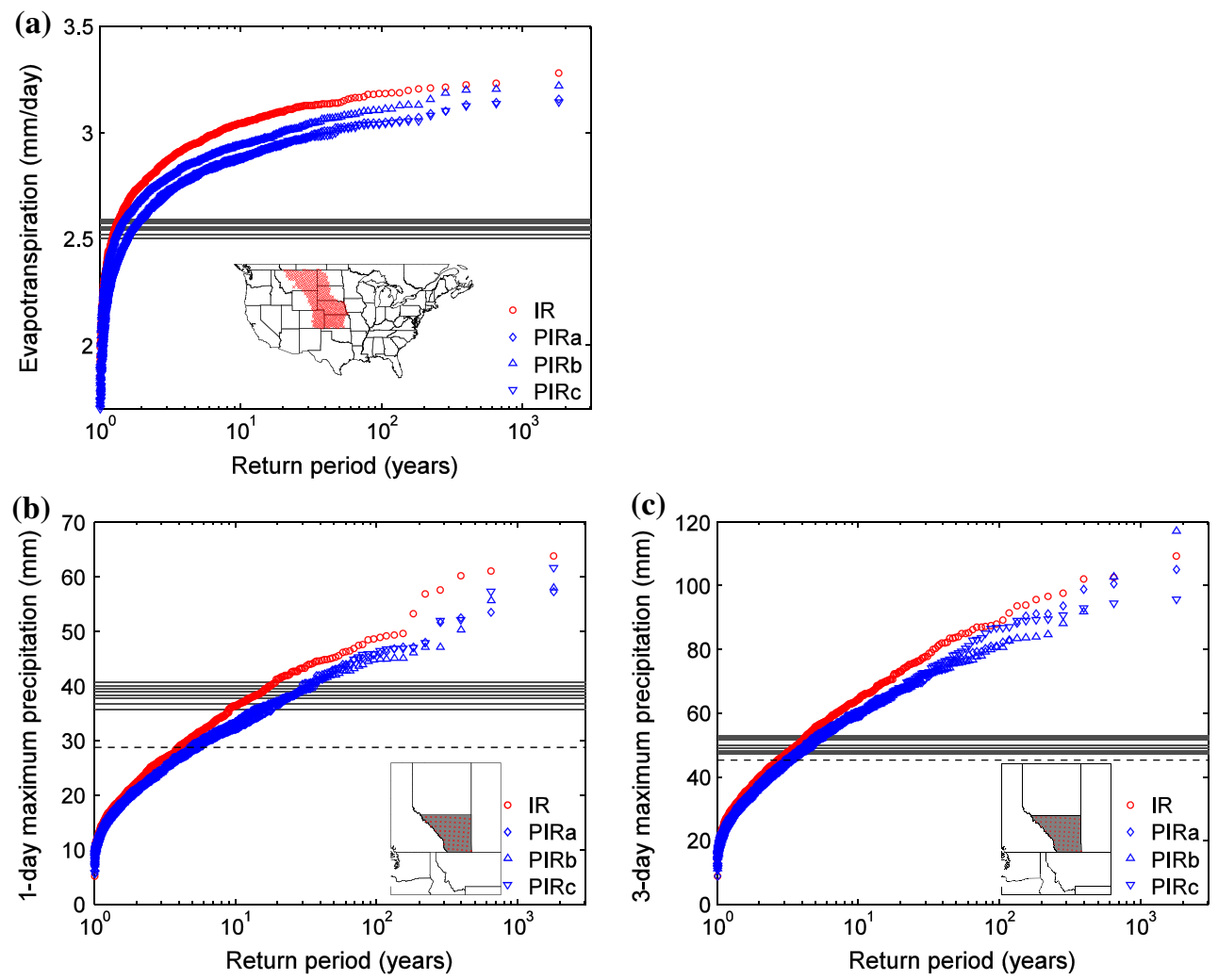

Fig. 13 Return times of a average May-June evapotranspiration over the northern Great Plains, b maximum 1-day and c 3-day May-June precipitation over southern Alberta, in present-day (red) and preindustrial ensembles (blue). Gray horizontal lines show a average evapotranspiration during the 14-21 June period, b average precipi-

several regions of interest. As already established from the sensitivity experiments discussed in previous sections, ET from the land surface played a role in contributing moisture to the 19-21 June precipitation event. The comparison of present-day and pre-industrial climates indicates a clearly attributable increase in ET over the Northern Great Plains for present-day climate, as shown in Fig. 13a. The modelled ET of around $2.55 \mathrm{~mm}$ per day during 14-21 June 2013 in the CRCM5_Ref simulation is not particularly unusual, representing an event that occurs more frequently than 1-in-2 years in both pre-industrial and present-day climates.

Over southern Alberta, 1-day maximum and 3-day maximum precipitation amounts are generally higher in the present-day climate than in the pre-industrial climates, for both 1-day and 3-day events (Fig. 13b, c). The 19-21 June event has simulated return times of 10-20 years for 1-day maximum precipitation and around 4 years for 3-day maximum precipitation over southern Alberta. For this region, anthropogenic GHG emissions are likely to have increased the probability of occurrence of extreme

tation on 20 June and $\mathbf{c}$ average precipitation during the 19-21 June period, for the members of the CRCM5_Ref ensemble. Black dashed lines show $\mathbf{b}$ average precipitation across the region on 20 June and $\mathbf{c}$ average precipitation during the 19-21 June period, as estimated from CaPA

precipitation events, including the heavy precipitation on 20 June 2013.

Focusing over the western BRB, only very slight increases in 1-day and 3-day precipitation return levels are observed in present-day climate (Fig. 14a, b) relative to the pre-industrial climate. The precipitation modelled by the nine members of CRCM5_Ref for 20 June by far exceeds a return time of 100 years, confirming that the combination of atmospheric factors that led to this event is extremely uncommon. For the 19-21 June event, the return time is around 50 years, which is consistent with the return times calculated from ANUSPLIN and CRCM5_ERA in the preceding section.

Runoff generation is complex, particularly during rainon-snow events with frozen ground. Though such events are more likely in the pre-industrial climate due to the longer snow cover periods, the higher intensity precipitation in present-day climate could lead to higher runoff. For 1-day maximum and 3-day maximum surface runoff over the western BRB, a discernable anthropogenic influence is not detected (Fig. 14c, d), as slightly increased precipitation might be balanced by decreased snowmelt and/or 

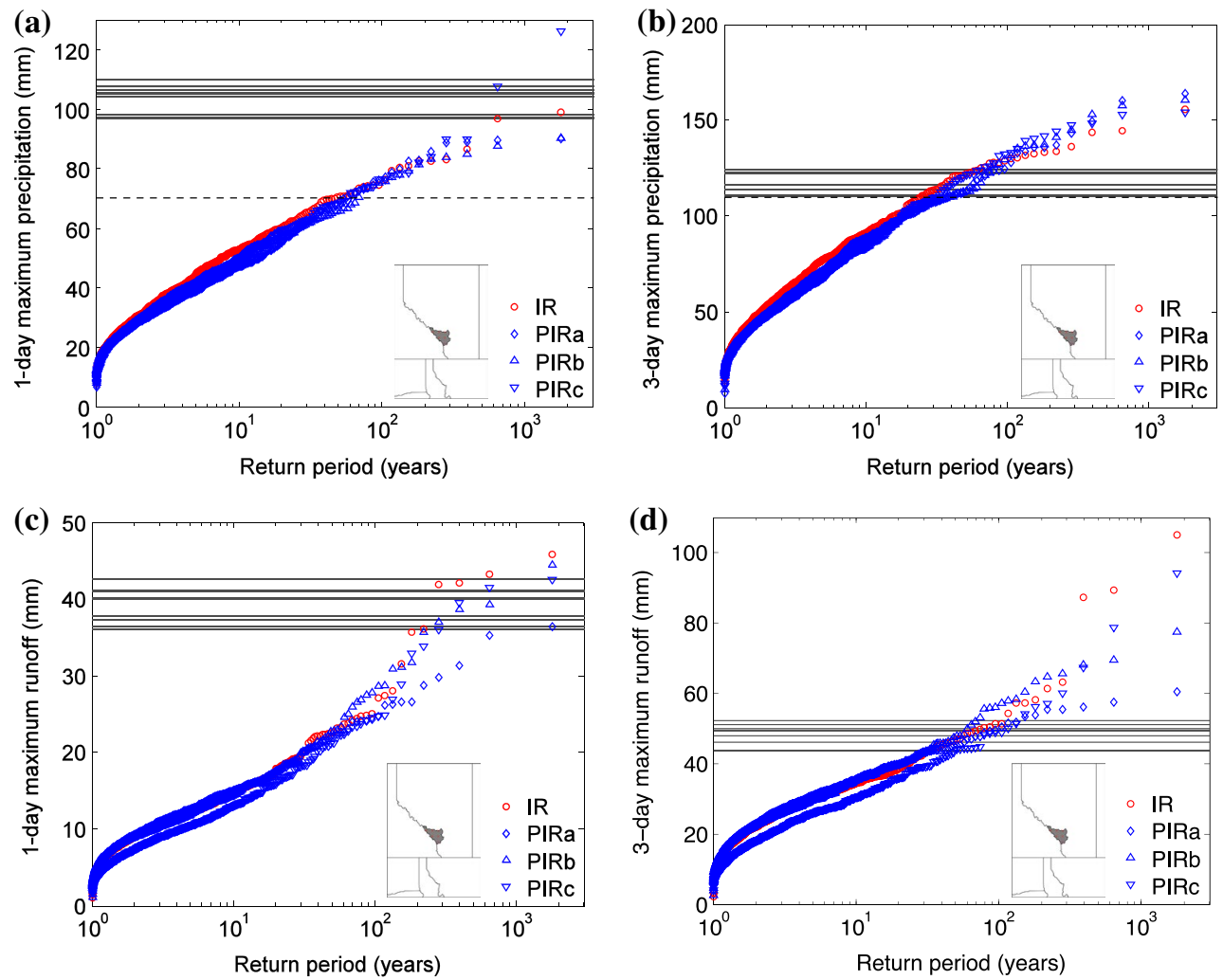

Fig. 14 Return times of maximum 1-day (left) and 3-day (right) May-June precipitation (top) and surface runoff (bottom) in presentday (red) and pre-industrial ensembles (blue), over the western BRB. Gray horizontal lines show the average precipitation (top) and average surface runoff (bottom) over this region on 20 June (left) and dur-

increased soil permeability due to reduced ice content. The surface runoff modelled by the nine members of CRCM5 Ref for 20 June exceeds a return time of 100 years. This is consistent with the extreme rainfall event affecting the snow-covered and frozen regions of the BRB, resulting in extreme surface runoff values.

While this study considered the anthropogenic influence on atmospheric GHG concentrations and SST/SIC when comparing present-day and pre-industrial climates, other components of the Earth system that have also been impacted by anthropogenic activities are not explored in this study, providing an opportunity for further research. One of these factors is land use change, which has been shown to be important, e.g. over the Canadian Prairies (Betts et al. 2013), as it alters the partitioning of energy at the Earth's surface.

\section{Summary and conclusions}

This paper investigates the meteorological and hydrological factors that played a role in the 2013 Alberta flood,

ing the 19-21 June period (right) for the members of the CRCM5 Ref ensemble. Black dashed lines show the average precipitation over this region on 20 June (top left) and during the 19-21 June period (top right), as estimated from $\mathrm{CaPA}$

from weather and climate perspectives, using CRCM5. The evaluation of CRCM5 against observations shows that the model reproduces the most important spatial and temporal features of the event, being especially skilful in simulating the core of intense precipitation over the foothills of the Canadian Rockies on 20 June, which was the main driver of the flooding.

From the weather perspective this study quantifies the contribution of orography, local and remote moisture sources, as well as rain-on-snow and soil moisture phase, to the Alberta flood event. The contribution of orographic ascent to precipitation is important, exceeding $30 \%$ over the region with the heaviest rainfall. Orographic ascent appears to have played a major role during most of the event, possibly excluding the first few hours, when quasigeostrophic ascent played the dominant role. ET from the land surface in several regions acted as a moisture source for the event, with the most important regions being the Prairies and the Great Plains, which are likely to have increased the atmospheric moisture available for the event. Rainfall over the Prairies and the Great Plains in the days preceding the event is likely to have enhanced the ET from 
the land surface by increasing near-surface soil moisture and thus favouring larger ET. Analysis suggests that the presence of frozen soil in the BRB is likely to have played a critical role in generating record streamflows, doubling the conversion rate of precipitation and snowmelt to surface runoff, while snowmelt itself contributed up to $25 \%$ of the modelled runoff.

From the climate perspective, the return time of the 3 -day precipitation event is estimated to exceed 50 years in the present-day climate over a large region of the foothills and peaks of the Canadian Rockies. An increase in the occurrence of similar extreme precipitation events is projected by the end of the 21st century under two different GHG concentration scenarios. Event attribution, which focuses on the comparison of present-day and pre-industrial climates, indicates a clearly attributable increase in ET for present-day climate in some of the regions that contributed moisture to the event. Similarly, over southern Alberta, 1-day maximum and 3-day precipitation return levels are slightly higher in present-day climate than in pre-industrial climate, suggesting that anthropogenic emissions played a role in the meteorological flood. However, no anthropogenic influence can be detected on the magnitude of the hydrological flood, as runoff generation is complex, and increases in extreme precipitation might be balanced by decreases in snow mass and frozen ground conditions.

Acknowledgments This work was carried out within the framework of the Natural Sciences and Engineering Research Council of CanadaClimate Change and Atmospheric Research (NSERC-CCAR) Program funded Canadian Network for Regional Climate and Weather Processes (CNRCWP). The CRCM5 code and simulations can be obtained from Centre ESCER via the corresponding author (teufel@ sca.uqam.ca).

Open Access This article is distributed under the terms of the Creative Commons Attribution 4.0 International License (http://creativecommons.org/licenses/by/4.0/), which permits unrestricted use, distribution, and reproduction in any medium, provided you give appropriate credit to the original author(s) and the source, provide a link to the Creative Commons license, and indicate if changes were made.

\section{References}

Barrett A (2003) National operational hydrologic remote sensing center snow data assimilation system (SNODAS) products at NSIDC. NSIDC Special Report 11

Belair S, Mailhot J, Girard C, Vaillancourt P (2005) Boundary layer and shallow cumulus clouds in a medium-range forecast of a large-scale weather system. Mon Weather Rev 133(7):1938-1960

Benoit R, Cote J, Mailhot J (1989) Inclusion of a TKE boundary-layer parameterization in the Canadian regional finite-element model. Mon Weather Rev 117(8):1726-1750

Betts AK, Desjardins R, Worth D, Cerkowniak D (2013) Impact of land use change on the diurnal cycle climate of the Canadian Prairies. J Geophys Res Atmos 118(21):11996-12011
Brubaker KL, Entekhabi D, Eagleson PS (1993) Estimation of continental precipitation recycling. J Clim 6(6):1077-1089

Caron LP, Jones CG, Winger K (2011) Impact of resolution and downscaling technique in simulating recent Atlantic tropical cylone activity. Clim Dyn 37(5-6):869-892

Christidis N, Stott PA, Scaife AA, Arribas A, Jones GS, Copsey D, Knight JR, Tennant WJ (2013) A new HadGEM3-A-based system for attribution of weather- and climate-related extreme events. J Clim 26(9):2756-2783

Cote J, Gravel S, Methot A, Patoine A, Roch M, Staniforth A (1998) The operational CMC-MRB Global Environmental Multiscale (GEM) model. Part I: design considerations and formulation. Mon Weather Rev 126(6):1373-1395

Dee DP, Uppala SM, Simmons AJ, Berrisford P, Poli P, Kobayashi S, Andrae U, Balmaseda MA, Balsamo G, Bauer P, Bechtold P, Beljaars ACM, van de Berg L, Bidlot J, Bormann N, Delsol C, Dragani R, Fuentes M, Geer AJ, Haimberger L, Healy SB, Hersbach $\mathrm{H}$, Holm EV, Isaksen L, Kallberg P, Kohler M, Matricardi M, McNally AP, Monge-Sanz BM, Morcrette JJ, Park BK, Peubey C, de Rosnay P, Tavolato C, Thepaut JN, Vitart F (2011) The ERA-Interim reanalysis: configuration and performance of the data assimilation system. Q J R Meteorol Soc 137(656):553-597

Delage Y (1997) Parameterising sub-grid scale vertical transport in atmospheric models under statically stable conditions. BoundLayer Meteorol 82(1):23-48

Delage Y, Girard C (1992) Stability functions correct at the free-convection limit and consistent for both the surface and Ekman layers. Bound-Layer Meteorol 58(1-2):19-31

Environment Canada (2014) Canada's top ten weather stories for 2013. http://ec.gc.ca/meteo-weather/default.asp?lang $=$ En $\& n=5$ BA5EAFC-1

Flesch TK, Reuter GW (2012) WRF model simulation of two Alberta flooding events and the impact of topography. J Hydrometeorol 13(2):695-708

Huziy O, Sushama L, Khaliq MN, Laprise R, Lehner B, Roy R (2013) Analysis of streamflow characteristics over Northeastern Canada in a changing climate. Clim Dyn 40(7-8):1879-1901

Kain JS, Fritsch JM (1990) A one-dimensional entraining detraining plume model and its application in convective parameterization. J Atmos Sci 47(23):2784-2802

Kay AL, Crooks SM, Pall P, Stone DA (2011) Attribution of Autumn/ Winter 2000 flood risk in England to anthropogenic climate change: a catchment-based study. J Hydrol 406(1-2):97-112

Kharin VV, Zwiers FW, Zhang X, Wehner M (2013) Changes in temperature and precipitation extremes in the CMIP5 ensemble. Clim Change 119(2):345-357

Kuo HL (1965) On formation and intensification of tropical cyclones through latent heat release by cumulus convection. J Atmos Sci 22(1):40-63

Laprise R (1992) The Euler equations of motion with hydrostaticpressure as an independent variable. Mon Weather Rev 120(1):197-208

Lehner B, Verdin K, Jarvis A (2008) New global hydrography derived from spaceborne elevation data. Eos Trans Am Geophys Union 89(10):93-94

Li J, Barker HW (2005) A radiation algorithm with correlatedk distribution. Part I: local thermal equilibrium. J Atmos Sci 62(2):286-309

Mahfouf JF, Brasnett B, Gagnon S (2007) A Canadian precipitation analysis (CaPA) project: description and preliminary results. Atmos Ocean 45(1):1-17

Markovic M, Lin H, Winger K (2012) Dynamical seasonal prediction using the global environmental multiscale model with a variable resolution modeling approach. Clim Dyn 39(7-8):1885-1904

Martynov A, Laprise R, Sushama L, Winger K, Separovic L, Dugas B (2013) Reanalysis-driven climate simulation over CORDEX 
North America domain using the Canadian Regional Climate Model, version 5: model performance evaluation. Clim Dyn 41(11-12):2973-3005

Mcfarlane NA (1987) The effect of orographically excited gravitywave drag on the general-circulation of the lower stratosphere and troposphere. J Atmos Sci 44(14):1775-1800

McKenney DW, Hutchinson MF, Papadopol P, Lawrence K, Pedlar J, Campbell K, Milewska E, Hopkinson RF, Price D, Owen T (2011) Customized spatial climate models for North America. Bull Am Meteorol Soc 92(12):1611-1622

Milrad SM, Gyakum JR, Atallah EH (2015) A meteorological analysis of the 2013 Alberta flood: antecedent large-scale flow pattern and synoptic-dynamic characteristics. Mon Weather Rev 143(7):2817-2841

Pall P, Aina T, Stone DA, Stott PA, Nozawa T, Hilberts AGJ, Lohmann D, Allen MR (2011) Anthropogenic greenhouse gas contribution to flood risk in England and Wales in autumn 2000. Nature 470(7334):382-385

Poitras V, Sushama L, Seglenieks F, Khaliq MN, Soulis E (2011) Projected changes to streamflow characteristics over Western Canada as simulated by the Canadian RCM. J Hydrometeorol 12(6):1395-1413

Pomeroy JW, Stewart RE, Whitfield PH (2016) The 2013 flood event in the South Saskatchewan and Elk River basins: causes, assessment and damages. Canadian Water Resour J 41(1-2):105-117. doi:10.1080/07011784.2015.1089190

Rex DF (1950) Blocking action in the middle troposphere and its effect upon regional climate. Tellus 2(3):196-211
Soulis ED, Snelgrove KR, Kouwen N, Seglenieks F, Verseghy DL (2000) Towards closing the vertical water balance in Canadian atmospheric models: coupling of the land surface scheme CLASS with the distributed hydrological model WATFLOOD. Atmos Ocean 38(1):251-269

Stott PA, Stone DA, Allen MR (2004) Human contribution to the European heatwave of 2003. Nature 432(7017):610-614

Sundqvist H, Berge E, Kristjansson JE (1989) Condensation and cloud parameterization studies with a mesoscale numerical weather prediction model. Mon Weather Rev 117(8):1641-1657

van Vuuren DP, Edmonds J, Kainuma M, Riahi K, Thomson A, Hibbard K, Hurtt GC, Kram T, Krey V, Lamarque JF, Masui T, Meinshausen M, Nakicenovic N, Smith SJ, Rose SK (2011) The representative concentration pathways: an overview. Clim Change 109(1-2):5-31

Verseghy DL (2011) CLASS-The Canadian land surface scheme (version 3.5), Technical Documentation (Version 1). Climate Research Division, Science and Technology Branch, Environment Canada

Yeh KS, Cote J, Gravel S, Methot A, Patoine A, Roch M, Staniforth A (2002) The CMC-MRB global environmental multiscale (GEM) model. Part III: Nonhydrostatic formulation. Mon Weather Rev 130(2):339-356

Zadra A, Roch M, Laroche S, Charron M (2003) The subgrid-scale orographic blocking parametrization of the GEM model. Atmos Ocean 41(2):155-170 